\title{
Bimetallic Pd-Co Nanoparticles Supported on Nitrogen-Doped Reduced Graphene Oxide as Efficient Electrocatalysts for Formic Acid Electrooxidation
}

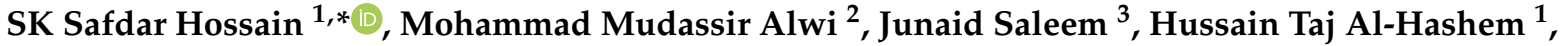 \\ Gordon McKay ${ }^{3}$, Said Mansour ${ }^{4}$ and Syed Sadiq Ali ${ }^{1}$
}

1 Department of Chemical Engineeriong, College of Engineering, P.O. Box 380, King Faisal University, Al-Ahsa 31982, Saudi Arabia; htalhashem@kfu.edu.sa (H.T.A.-H.); ssali@kfu.edu.sa (S.S.A.)

2 Department of Mechanical Engineering, College of Engineering, King Faisal University, Al-Ahsa 31982, Saudi Arabia; malwi@kfu.edu.sa

3 Division of Sustainable Development, College of Science and Engineering, Hamad Bin Khalifa University, Qatar Foundation, Doha, Qatar; jsaleem@hbku.edu.qa (J.S.); gmckay@hbku.edu.qa (G.M.)

4 Qatar Environment and Energy Research Institute, Hamad Bin Khalifa University, Qatar Foundation, Doha, Qatar; smansour@hbku.edu.qa

* Correspondence: snooruddin@kfu.edu.sa; Tel.: +966-13-589-5437; Fax: +966-13-581-7068

\section{check for} updates

Citation: Hossain, S.S.; Alwi, M.M.; Saleem, J.; Al-Hashem, H.T.; McKay, G.; Mansour, S.; Ali, S.S. Bimetallic Pd-Co Nanoparticles Supported on Nitrogen-Doped Reduced Graphene Oxide as Efficient Electrocatalysts for Formic Acid Electrooxidation. Catalysts 2021, 11, 910. https:// doi.org/10.3390/catal11080910

Academic Editors: Donald Tryk and Guoyu Shi

Received: 28 June 2021

Accepted: 25 July 2021

Published: 28 July 2021

Publisher's Note: MDPI stays neutral with regard to jurisdictional claims in published maps and institutional affiliations.

Copyright: (c) 2021 by the authors. Licensee MDPI, Basel, Switzerland. This article is an open access article distributed under the terms and conditions of the Creative Commons Attribution (CC BY) license (https:/ / creativecommons.org/licenses/by/ $4.0 /)$.

\begin{abstract}
In this work, bimetallic $\mathrm{Pd}_{\mathrm{x}} \mathrm{Co}_{\mathrm{y}}$ nanoparticles supported on nitrogen-doped reduced graphene oxide catalysts were synthesized and tested for formic acid oxidation as potentially efficient and durable electrocatalysts. Graphene oxide was nitrogen doped through hydrothermal chemical reduction with urea as a nitrogen source. The $\mathrm{Pd}_{\mathrm{x}} \mathrm{Co}_{\mathrm{y}}$ nanoparticles were deposited on the nitrogendoped graphene oxide support using the impregnation-reduction method with sodium borohydride as a reducing agent and sodium citrate dihydrate as a stabilizing agent. The structural features, such as phases, composition, oxidation states, and particle sizes, of the nanoparticles were characterized using X-ray diffraction, transmission electron microscopy, scanning electron microscopy-energydispersive $\mathrm{X}$-ray spectroscopy, and $\mathrm{X}$-ray photoelectron spectroscopy. The $\mathrm{Pd}$ nanoparticle sizes in $\mathrm{Pd}_{1} \mathrm{Co}_{1} / \mathrm{N}-\mathrm{rGO}, \mathrm{Pd} / \mathrm{N}-\mathrm{rGO}$, and $\mathrm{Pd}_{1} \mathrm{Co}_{1} / \mathrm{CNT}$ were $3.5,12.51$, and $4.62 \mathrm{~nm}$, respectively. The electrochemical performance of the catalysts was determined by $\mathrm{CO}$ stripping, cyclic voltammetry, and chronoamperometry. $\mathrm{Pd}_{1} \mathrm{Co}_{1} / \mathrm{N}-\mathrm{rGO}$ showed the highest mass activity of $4833.12 \mathrm{~mA}^{-1} \mathrm{mg}$ $\mathrm{Pd}$, which was twice that of $\mathrm{Pd}_{1} \mathrm{Co}_{1} / \mathrm{CNT}$. Moreover, $\mathrm{Pd}_{1} \mathrm{Co}_{1} / \mathrm{N}-\mathrm{rGO}$ showed a steady-state current density of $700 \mathrm{~mA}^{-1} \mathrm{mg}$ Pd after $5000 \mathrm{~s}$ in chronoamperometry carried out at $+0.35 \mathrm{~V}$. Apart from the well-known bifunctional effect of $\mathrm{Co}$, nitrogen-doped graphene contributed to the performance enhancement of the $\mathrm{Pd}_{1} \mathrm{Co}_{1} / \mathrm{N}$-rGO catalyst.
\end{abstract}

Keywords: formic acid oxidation; anode catalyst; $\mathrm{Pd}_{\mathrm{x}} \mathrm{Co}_{\mathrm{y}} / \mathrm{N}-\mathrm{rGO}$ electrocatalyst; $\mathrm{CO}$ stripping; cyclic voltammetry

\section{Introduction}

Fuel cells have gained significant attraction as a sustainable and clean source of energy. The polymer electrolyte membrane (PEM) fuel cell is a class of fuel cells suitable for portable electronic devices and automobiles [1]. Hydrogen and other compounds (methanol, ethanol, formic acid, ammonia) are the leading choices for the anode feed of PEM fuel cells [2]. However, formic acid stands out among the alternatives because of its non-toxicity and low permeation through proton-conducting membranes $[3,4]$. Direct formic acid fuel cells (DFAFCs) are PEM fuel cells that use formic acid as an anode feed. The electric current in DFAFCs is generated via the electrooxidation of formic acid at the anode and reduction of oxygen at the cathode [5]. Although the overall performance of DFAFCs depends on the thermodynamics and kinetics of anodic and cathodic reactions, the formic acid oxidation (FAO) reaction at the anode is usually the limiting reaction [6]. 
FAO can occur via direct or indirect pathways [7]. FAO occurs predominantly through a direct pathway $\left(\mathrm{HCOOH} \rightarrow \mathrm{CO}_{2}+2 \mathrm{H}^{+}+2 \mathrm{e}^{-}\right.$) over palladium-based catalysts, whereas $\mathrm{Pt}$ surface oxidation occurs via an indirect pathway $\left(\mathrm{HCOOH} \rightarrow \mathrm{CO}_{\mathrm{ad}}+\mathrm{H}_{2} \mathrm{O} \rightarrow \mathrm{CO}_{2}+\right.$ $\left.2 \mathrm{H}^{+}+2 \mathrm{e}^{-}\right)[7,8]$. Pt-based catalysts experience severe activity loss due to poisoning by carbon monoxide (CO) formed in the indirect pathway [6,8]. However, Pd is relatively cheaper, more abundant, more active, and more durable than Pt [9]. In addition, Pd-based electrocatalysts show better activity and stability by promoting the direct pathway where $\mathrm{CO}$ is not produced as an intermediate. However, Pd-based catalysts are still far from the performance level required to commercialize DFAFCs [10]. The below-expectation activity of the current electrocatalysts is related to the poor particle size control and agglomeration during synthesis, CO poisoning, and poor metal-support interaction. In the literature, two major strategies that have been suggested to improve the performance of Pd catalysts are (1) adding one or more transition metal(s) to the Pd and (2) using high-performance support materials.

Support materials control the size distribution, dispersion, and electronic state of the incoming metal nanoparticle(s) through the metal-support interaction [11,12]. Vulcan carbon is the most widely used support in PEM fuel cells. However, it shows a low surface area, a large proportion of micropores, an inert chemical structure, and corrosion in acidic and alkaline environments [13]. Significant improvements in the performance of catalysts for FAO have been reported with carbon nanotubes (CNTs) [14,15], carbon nanofibers [16], ordered mesoporous carbon (OMC) [17], and grapheme [18]. Graphene and its various forms, such as graphene, graphene oxide, and partially reduced graphene oxide, have been explored as a support for FAO [19]. Graphene oxide possesses high electrical conductivity, an enhanced surface area, and high stability [20]. Doping of graphene oxide with heteroatoms, such as nitrogen, phosphorus, fluorine, and sulfur, is an effective technique to improve the structural and chemical properties of graphene oxide [21,22]. Nitrogen as a dopant for graphene oxide offers advantages, such as high electronegativity and an atomic size comparable with carbon $[23,24]$. Nitrogen-doped reduced graphene oxide (N-rGO) facilitates the nucleation and growth behavior of nanoparticles, which causes an improved distribution of metal nanoparticles on the support [23-26]. Chowdhury et al. reported that nitrogen-doped reduced graphene oxide plays a vital role in improving the performance of supported PdCu nanoparticle catalysts for FAO. First, electron-rich nitrogen atoms in the carbon structure of graphene oxide cause the delocalization of electrons, resulting in the enhanced electron transfer rate and additional active sites on the graphene structure. In addition, nitrogen-doped graphene oxide assists in the formation of highly dispersed $\mathrm{PdCu}$ nanoparticles by modulating the nucleation and growth mechanism of nanoparticles [27]. Similar results have been reported by Sun et al. [28] and Hossain et al. [12].

Cobalt is a good adatom candidate because it is cheap and imparts favorable effects on the Pd metal. Cobalt helps the oxidation of intermediates formed on the Pd particles through the bi-functional mechanism, which frees the Pd particles for further oxidation. Bimetallic $\mathrm{PdCo} / \mathrm{C}$ shows improved $\mathrm{CO}$ oxidation activity as evidenced by a negative $(-0.9 \mathrm{~V})$ shift of the CO oxidation peak compared with $\mathrm{Pd} / \mathrm{C}$ [29]. Lui et al. synthesized PdCo supported on carbon nanofibers by electrospinning acetate precursors. The improved performance in $\mathrm{PdCo} / \mathrm{CNF}$ compared with $\mathrm{Pd} / \mathrm{C}$ can be ascribed to the bifunctional effect, electronic modification of $\mathrm{d}$-orbital of $\mathrm{Pd}$, and improved dispersion and attachment of nanoparticles over carbon nanofibers [16]. PdCo nanoparticles supported on CNTs [15] and OMC [17] and graphene [18] have shown good performance. Recently, Douk et al. have shown that graphene supports PdCo better than Pd/C [18]. Therefore, PdCo bimetallic nanoparticles are excellent catalysts for FAO. However, PdCo nanoparticles supported on nitrogen-doped reduced graphene oxide electrocatalysts for FAO have not been reported so far.

The present work aimed to synthesize nitrogen-doped reduced graphene oxide using graphene oxide as a precursor and evaluate its performance as a support material of 
PdCo nanoparticles for FAO. In the first step, nitrogen doping and partial reduction of graphene oxide were carried out simultaneously by hydrothermal treatment with urea. Then, the resulting N-rGO-supported PdCo nanoparticles were synthesized in various ratios (1:1, 3:1, and 1:3) through borohydride reduction. $\mathrm{PdCo}(1: 1)$ supported on CNTs and $\mathrm{Pd} / \mathrm{N}-\mathrm{rGO}$ have been prepared for comparison using a similar procedure and synthesis condition. The metal content in the synthesized catalysts was maintained at $20 \mathrm{wt} \%$. Cyclic voltammetry $(\mathrm{CV})$, chronoamperometry $(\mathrm{CA})$, and $\mathrm{CO}$ striping studies were performed to evaluate the performance of the catalysts for FAO. The activity-structure relationship was established by characterizing the morphology, structure, and chemical properties of the catalysts through X-ray diffraction (XRD), scanning electron microscopy-energydispersive X-ray spectroscopy (SEM-EDX), transmission electron microscopy (TEM), and $\mathrm{X}$-ray photoelectron spectroscopy (XPS).

\section{Results and Discussion}

\subsection{Catalyst Characterizations}

\subsubsection{X-ray Diffraction}

The XRD spectrum for the synthesized catalysts was generated to identify the chemical nature of phases and the crystalline size. Figure 1 shows the diffraction patterns of $\mathrm{Pd} / \mathrm{N}$ $\mathrm{rGO}, \mathrm{Pd}_{3} \mathrm{Co} / \mathrm{N}-\mathrm{rGO}, \mathrm{PdCo}_{3} / \mathrm{N}-\mathrm{rGO}, \mathrm{Pd}_{1} \mathrm{Co}_{1} / \mathrm{N}-\mathrm{rGO}$, and $\mathrm{Pd}_{1} \mathrm{Co}_{1} / \mathrm{CNT}$. A prominent peak at around $26^{\circ}$ visible in all the catalysts arises from the graphite plane (002) associated with the nitrogen-doped graphene and CNT support materials. In addition to the graphitic peak, the catalysts (Figure 2A-E) display diffraction peaks at $40.58^{\circ}, 47.01^{\circ}, 68.98^{\circ}$, and $83.65^{\circ}$, which correspond to the lattice planes (111), (200), (220), and (311) of the facecentered cubic crystal structure Pd (JCPDS Card\# 46-1043). Additional peaks at $35.19^{\circ}$, $54.12^{\circ}$, and $60.12^{\circ}$ in the case of $\mathrm{Pd} / \mathrm{N}-\mathrm{rGO}$ without heat treatment (Figure $2 \mathrm{C}$ ) indicate the presence of tetragonal PdO (JCPDS\#85-071). $\mathrm{Pd}(\mathrm{OH})_{2}$ formed from the hydrolysis of $\mathrm{Pd}\left(\mathrm{NO}_{3}\right)_{2}$ is not completely reduced to the metal $\mathrm{Pd}(\mathrm{o})$ by the sodium borohydride alone. Heat treatment at $450{ }^{\circ} \mathrm{C}$ in the presence of hydrogen effectively converts $\mathrm{PdO}$ completely to metallic Pd. In comparison with Pd/N-rGO, no specific shift in the Pd (111) position is observed with $\mathrm{Pd}_{\mathrm{x}} \mathrm{Co}_{\mathrm{y}} / \mathrm{N}$-rGO. However, the $\mathrm{Pd}(111)$ peak in the heat-treated N-rGOsupported catalysts, $\mathrm{Pd}_{\mathrm{x}} \mathrm{Co}_{\mathrm{y}} / \mathrm{N}-\mathrm{rGO}$ and $\mathrm{Pd} / \mathrm{NrGO}$, shows a positive shift compared with $\mathrm{Pd}_{1} \mathrm{Co}_{1} / \mathrm{CNT}$. This phenomenon could be due to the better metal-support interaction arising from the N-rGO support. No peak associated with the cobalt is detectable in the catalysts. This result does not mean that Co is not present in the sample; rather, it is due to less cobalt being added and the small atomic diameter of cobalt [30]. The average crystalline size of the particles is calculated using the Scherrer equation $d=\frac{0.9 \lambda}{\beta \cos \theta}$, where $\beta=$ Full Width Half Max (radians), and $\lambda=$ wavelength $(0.15406 \mathrm{~nm})$. The average crystallite size of the catalysts is shown in Table 1.

Table 1. XRD and TEM analyses of the as-prepared catalysts.

\begin{tabular}{ccccc}
\hline \multirow{2}{*}{ Catalyst } & 2theta & FWHM & \multicolumn{2}{c}{ Average Particle Size (nm) } \\
\cline { 4 - 5 } & & & XRD & TEM \\
\hline $\mathrm{Pd}_{3} \mathrm{Co} / \mathrm{N}-\mathrm{rGO}$ & 40.70 & 1.15 & $7.36 \pm 0.5$ & - \\
\hline $\mathrm{Pd}_{1} \mathrm{Co}_{1} / \mathrm{N}-\mathrm{rGO}$ & 40.95 & 1.53 & $5.54 \pm 0.5$ & $3.5 \pm 0.5$ \\
\hline $\mathrm{PdCo}_{3} / \mathrm{N}-\mathrm{rGO}$ & 40.89 & 1.70 & $4.97 \pm 0.5$ & - \\
\hline $\begin{array}{c}\mathrm{Pd}_{3} \mathrm{Co} / \mathrm{N}-\mathrm{rGO} \\
(\text { without heat })\end{array}$ & 40.12 & 1.64 & $5.13 \pm 0.5$ & - \\
\hline $\mathrm{Pd} / \mathrm{N}-\mathrm{rGO}$ & 40.58 & 1.46 & $8.79 \pm 0.5$ & $12.51 \pm 0.5$ \\
\hline $\mathrm{Pd}_{1} \mathrm{Co}_{1} / \mathrm{CNT}$ & 40.380 & 1.22 & $6.50 \pm 0.5$ & $4.62 \pm 0.5$ \\
\hline
\end{tabular}




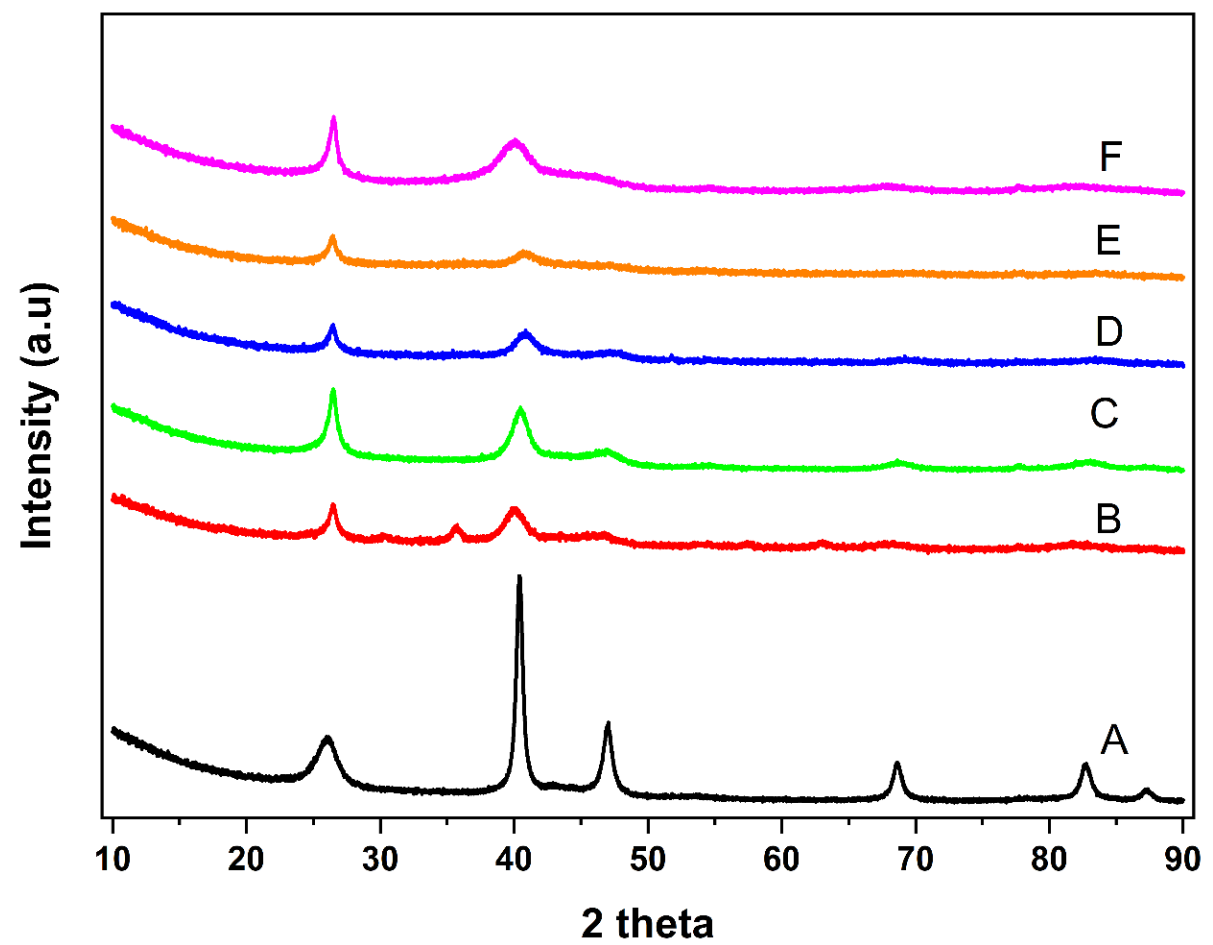

Figure 1. X-ray diffraction pattern for (A) $\mathrm{Pd}_{1} \mathrm{Co}_{1} / \mathrm{CNT}$, (B) $\mathrm{Pd} / \mathrm{N}-\mathrm{rGO}$ without hydrogen treatment $\mathrm{Pd} / \mathrm{N}-\mathrm{rGO},(\mathrm{C}) \mathrm{Pd} / \mathrm{N}-\mathrm{rGO}$, (D) $\mathrm{Pd}_{1} \mathrm{Co}_{1} / \mathrm{N}-\mathrm{rGO}$, (E) $\mathrm{PdCo}_{3} / \mathrm{N}-\mathrm{rGO}$, and (F) $\mathrm{Pd}_{3} \mathrm{Co} / \mathrm{N}-\mathrm{rGO}$.
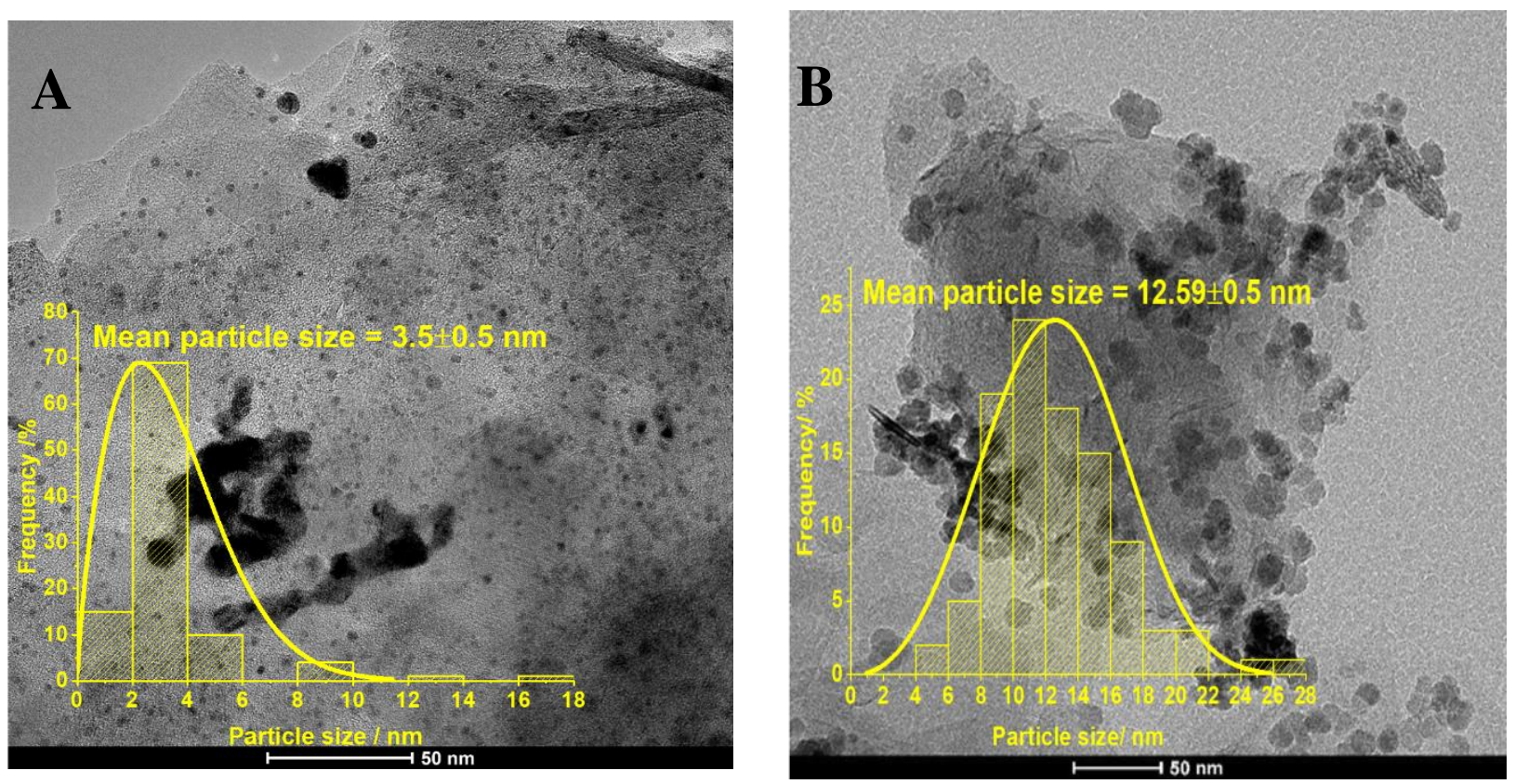

Figure 2. Cont. 


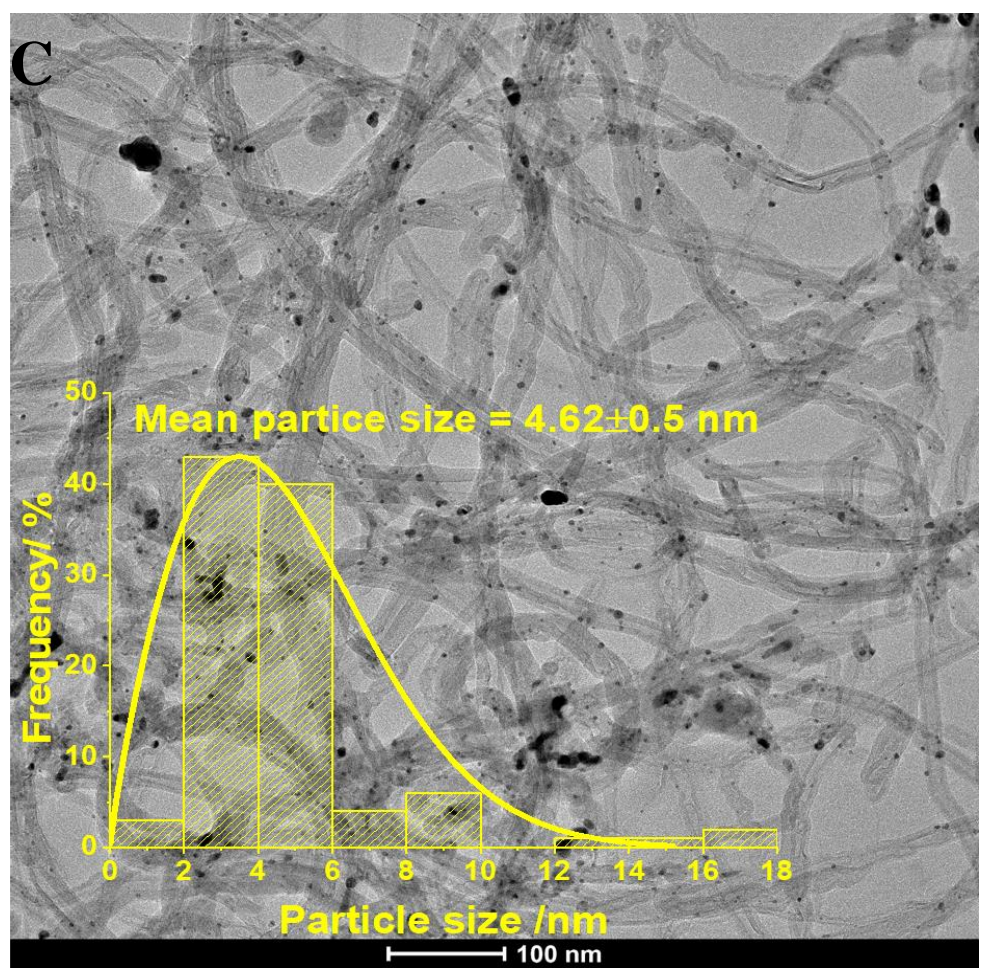

Figure 2. Transmission electron microscopy for (A) $\mathrm{Pd}_{1} \mathrm{Co}_{1} / \mathrm{N}-\mathrm{rGO}$ catalyst, (B) Pd/N-rGO, and $(\mathbf{C}) \mathrm{Pd}_{1} \mathrm{Co}_{1} / \mathrm{CNT}$

\subsubsection{Transmission Electron Microscopy}

Figure $2 \mathrm{~A}-\mathrm{C}$ shows the TEM images of the $\mathrm{Pd}_{1} \mathrm{Co}_{1} / \mathrm{N}-\mathrm{rGO}, \mathrm{Pd} / \mathrm{N}-\mathrm{rGO}$, and $\mathrm{Pd}_{1} \mathrm{Co}_{1} / \mathrm{CNT}$ catalysts and their associated particle size distribution histogram. TEM is an effective technique to understand the dispersion and size of the metal nanoparticles on the surface of support materials. As shown in Figure 2A, finely dispersed PdCo alloy nanoparticles are evenly dispersed on the nitrogen-doped reduced graphene oxide. The characteristics of the wrinkle-like structure of grapheme [27] are clearly visible, proving that the primary structure of the starting material graphene is retained even after incorporating nitrogen dopant and $\mathrm{Pd}$ and Co nanoparticles. The particle size distribution for the PdCo nanoparticles is presented as a histogram. The average particle size is $3.5 \mathrm{~nm}$. For estimating the average particle size, 200 nanoparticles were randomly selected, and particle size averaging was conducted. The nanoparticles are mainly in the particle size range of 2-10 nm, except for a few larger agglomerated particles $(16-18 \mathrm{~nm})$. These few agglomerations could have resulted from the heat treatment at $450{ }^{\circ} \mathrm{C}$. For Pd/N-rGO, larger particles of PdCo are observed with an average particle size of $12.51 \mathrm{~nm}$. Therefore, Co nanoparticles hinder the growth of $\mathrm{Pd}$ nanoparticles in $\mathrm{Pd}_{1} \mathrm{Co}_{1} / \mathrm{N}-\mathrm{rGO}$. A TEM image of $\mathrm{Pd}_{1} \mathrm{Co}_{1}$ supported CNT with a histogram is shown in Figure 2C. Narrowly sized $(2-8 \mathrm{~nm})$ PdCo nanoparticles are evenly attached to the rope-like CNT structure. The average particle size of the $\mathrm{PdCo}$ nanoparticles was calculated to be $4.62 \mathrm{~nm}$, which is slightly larger than $\mathrm{Pd}_{1} \mathrm{Co}_{1} / \mathrm{N}-\mathrm{rGO}$. The particle size of the Pd or Pd alloy nanoparticles has a considerable impact on the activity of the catalysts for the FAO reaction [31]. Zhou et al. reported that the optimum particle size for the overall FAO is $5-7 \mathrm{~nm}$. However, smaller particles are preferred because of the larger electrochemical surface area (ECSA) [32]. The PdCo nanoparticles in our case are most likely to provide excellent activity because they are near the desired particle size range. The particles calculated from TEM are close to the values calculated from the XRD (Table 1). 


\subsubsection{Scanning Electron Microscopy}

SEM images for $\mathrm{Pd}_{1} \mathrm{Co}_{1} / \mathrm{N}-\mathrm{rGO}$ and $\mathrm{Pd}_{1} \mathrm{Co}_{1} / \mathrm{CNT}$ were obtained using a JEOL SEM JSM-6300 with an energy-dispersive spectrometer. Figure 3 shows the SEM analysis of the $\mathrm{Pd}_{1} \mathrm{Co}_{1} / \mathrm{OMC}(\mathrm{A}-\mathrm{B})$ and $\mathrm{Pd}_{1} \mathrm{Co}_{1} / \mathrm{CNT}(\mathrm{C}-\mathrm{D})$ catalysts. Figure $3 \mathrm{~A}$ illustrates a typical graphene-like exfoliated and wavy morphology for the $\mathrm{Pd}_{1} \mathrm{Co}_{1} / \mathrm{N}-\mathrm{rGO}$ catalyst. The nitrogen content on the $\mathrm{N}-\mathrm{rGO}$ and $\mathrm{Pd}_{1} \mathrm{CO}_{1} / \mathrm{N}-\mathrm{rGO}$ catalyst are 4.54 and $2.96 \%$ (by atomic $\%$ ), as inferred from the EDX spectrum (Figure 3B). The Pd and Co contents in the $\mathrm{Pd}_{1} \mathrm{CO}_{1} / \mathrm{N}-\mathrm{rGO}$ catalyst are 14.10 and $2.16 \mathrm{wt} \%$, respectively. Long, elongated spaghettilike structures of CNTs are clearly visible in Figure 3C. A bright layer is prominently visible on the CNT surface because of the metal coating. The presence of Pd, Co, and C can be confirmed by the EDX spectrum of a specific section of the catalyst in Figure 3D.
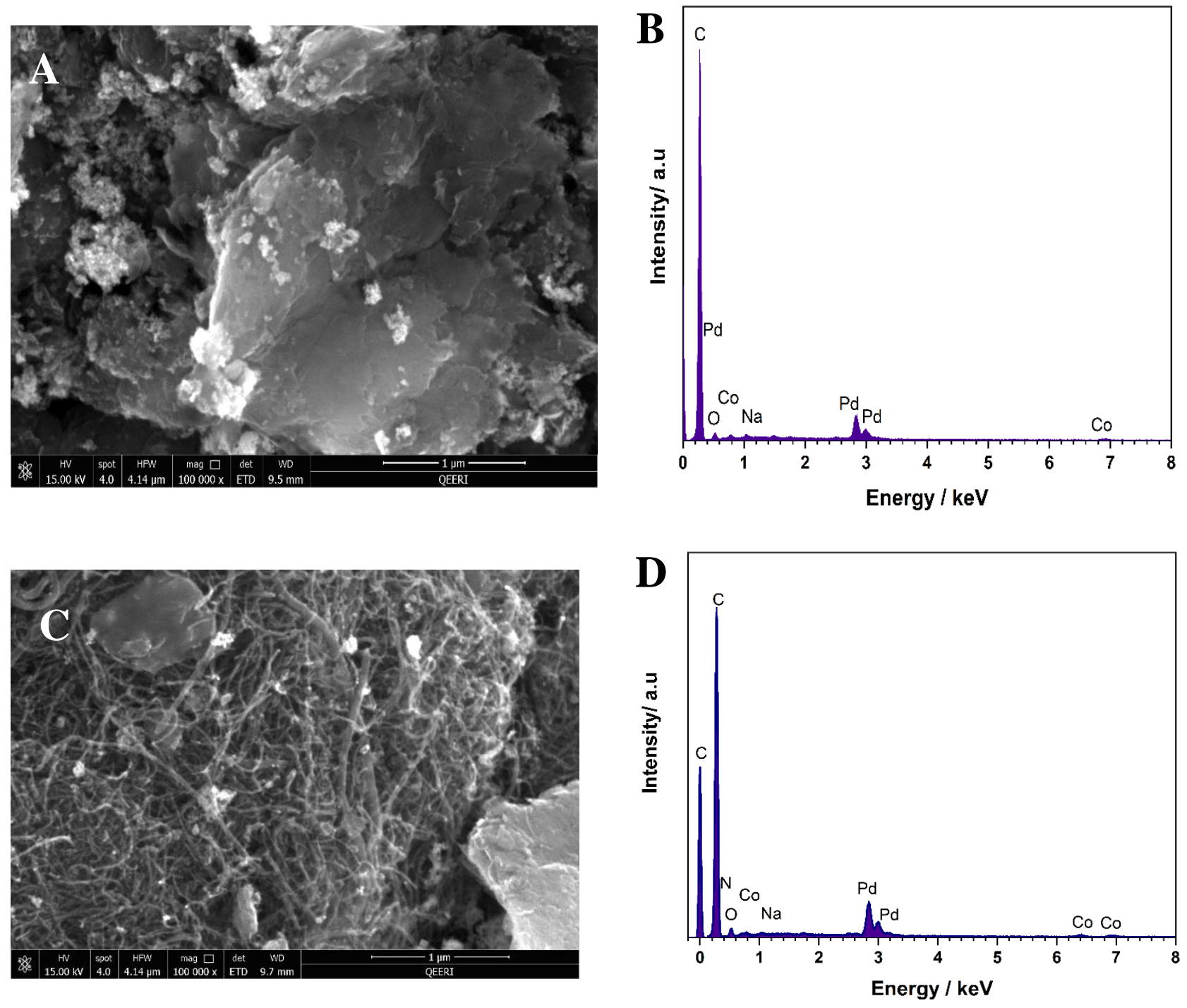

Figure 3. Scanning electron microscopy image and energy-dispersive X-ray spectra for $(\mathbf{A}, \mathbf{B}) \mathrm{Pd}_{1} \mathrm{Co}_{1} / \mathrm{N}-\mathrm{rGO}$ and $(\mathbf{C}, \mathbf{D})$ $\mathrm{Pd}_{1} \mathrm{Co}_{1} / \mathrm{CNT}$.

\subsubsection{X-ray Photoelectron Spectroscopy}

XPS studies were carried out to understand the nature of the chemical states of metals and nitrogen species present in $\mathrm{Pd}_{1} \mathrm{Co}_{1} / \mathrm{N}-\mathrm{rGO}$ and how these species interact. XPS study deciphers how the electronic properties of the active metal Pd are modulated by the cobalt and different nitrogen species present in $\mathrm{Pd}_{1} \mathrm{Co}_{1} / \mathrm{N}-\mathrm{rGO}$. Figure $4 \mathrm{~A}$ shows the 
overall XPS spectrum for the $\mathrm{Pd}_{1} \mathrm{Co}_{1} / \mathrm{N}-\mathrm{rGO}$ catalyst. The spectrum contains a prominent peak associated with carbon at $280-290 \mathrm{eV}$, followed by smaller peaks of $\mathrm{Pd}(334-345 \mathrm{eV})$, nitrogen (394-404 eV), oxygen $(580 \mathrm{eV})$, and cobalt $(790 \mathrm{eV})$. Importantly, the nitrogen peak in the spectrum indicates that the hydrothermal treatment of graphene oxide with urea is an effective strategy to dope nitrogen into the graphene oxide structure. The individual peaks were deconvoluted using the Origin software to study further the exact nature of the chemical species associated with the peaks. The deconvoluted carbon peaks at 284.34, 284.60, 285.56, and $290.56 \mathrm{eV}$ in Figure 4B could be associated with the C-C, C-N, C=O, and $\mathrm{O}-\mathrm{C}=\mathrm{O}$ bonds present in the graphene structure of $\mathrm{Pd}_{1} \mathrm{Co}_{1} / \mathrm{N}-\mathrm{rGO}$. The formation of the $\mathrm{C}-\mathrm{N}$ bond shows that the nitrogen is covalently bonded to the carbon, not just any physical trapping or loose physical bondage. In Figure $4 \mathrm{C}$, the deconvoluted peak of the $\mathrm{O} 1$ s spectrum confirms the presence of $\mathrm{C}=\mathrm{O}$ and $\mathrm{O}=\mathrm{C}-\mathrm{O}$ functional groups at binding energies of 531.54 and $534.1 \mathrm{eV}$, respectively.
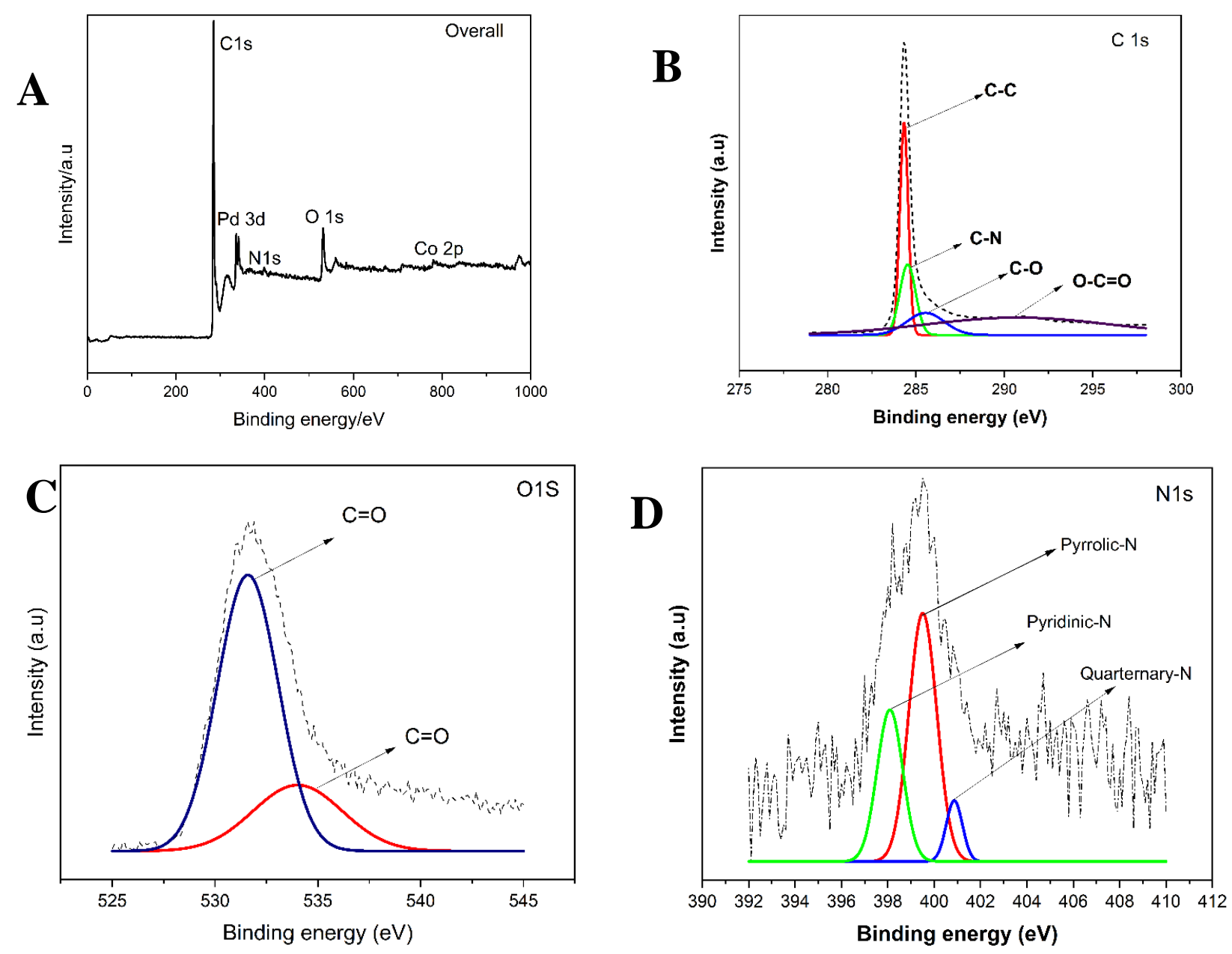

Figure 4. Cont. 

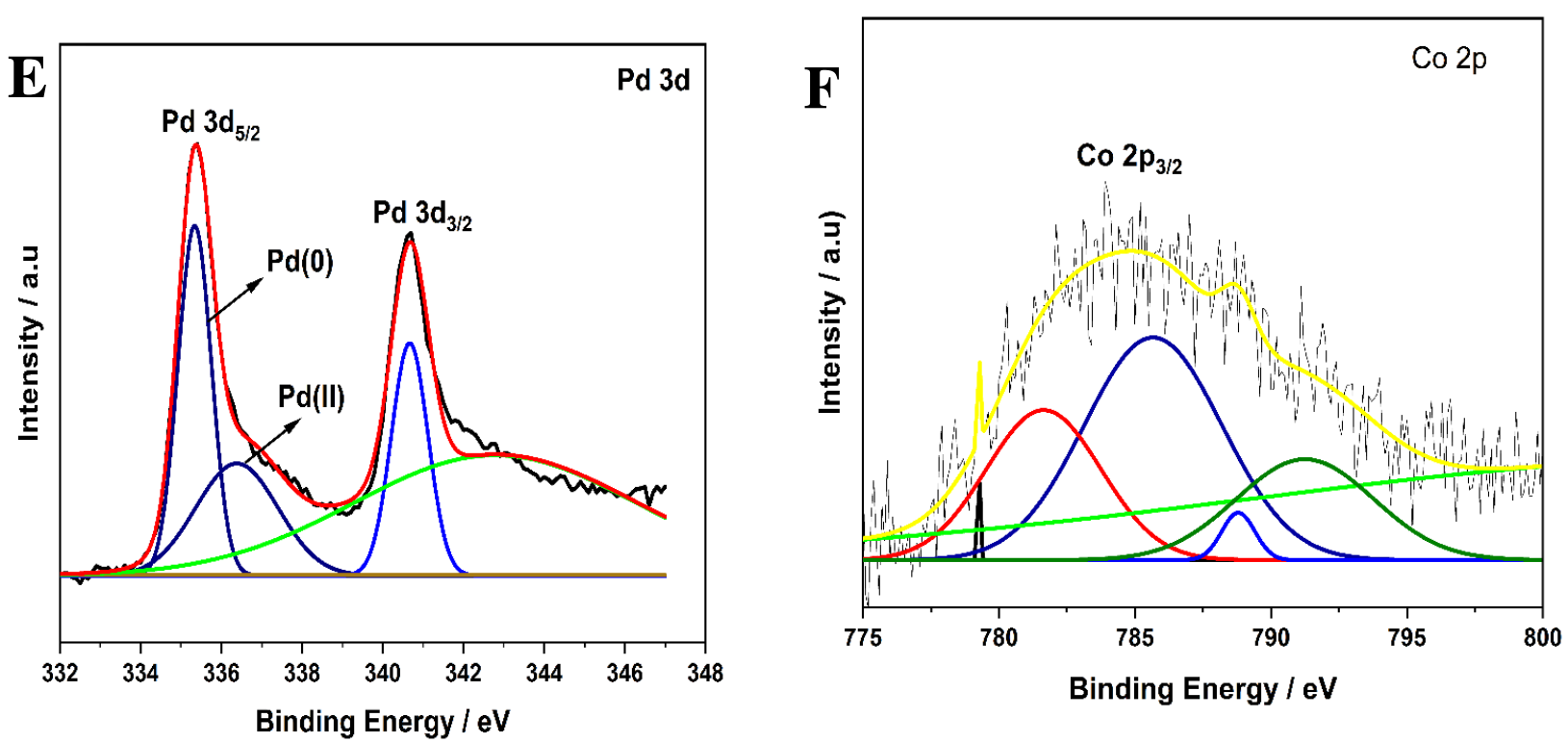

Figure 4. X-ray photoelectron spectroscopy spectra for $\mathrm{Pd}_{1} \mathrm{Co}_{1} / \mathrm{N}-\mathrm{rGO}$ catalyst (A) overall spectra, (B) C1s, (C) O1s (D) N1s, (E) Pd, (F) Co2p.

The nitrogen atom bonded to the carbon in the graphene structure in N-doped graphene oxide appears in four configurations, namely, pyridinic- $\mathrm{N}$, pyrrolic- $\mathrm{N}$, graphitic or quaternary nitrogen, and oxides of pyridinic $\mathrm{N}$, depending upon the nature of bonding configurations in the graphene carbon network $[23,24]$. In Figure 4D, three peaks corresponding to pyridinic-N, pyrrolic-N, graphitic, or quaternary nitrogen are recognized. These nitrogen species affect electronic configuration and electron distribution over $\mathrm{Pd}$ to a different extent because of the different $\mathrm{C}-\mathrm{N}$ bonding configurations [24,25]. A consensus on which of the nitrogen configurations is the most actively responsible for enhancing the activity for the electrooxidation reactions has yet to be reached [33]. However, the proportion of the different configurations in N-graphene possibly directly influences the catalytic activity of the electrocatalysts. Wang et al. suggested that pyridinic-N and graphitic-N promote higher activity [23]. However, Jiang et al. concluded from experimental and DFT studies that pyrrolic-N in Pd catalysts shows high activity and fast reaction kinetics for FAO [34]. The proportion of pyrrolic-N in $\mathrm{Pd}_{1} \mathrm{Co}_{1} / \mathrm{N}-\mathrm{rGO}$ was calculated to be $65 \%$ by integrating the area under the curve. Thus, $\mathrm{Pd}_{x} \mathrm{Co}_{y} / \mathrm{N}-\mathrm{rGO}$ is expected to show high activity for FAO.

In the spectrum for $\mathrm{Pd}$, two peaks at 335.37 and $340.63 \mathrm{eV}$ represent the $3 \mathrm{~d}_{5 / 2}$ and $3 d_{3 / 2}$ states of the zero-valent $P d$, respectively. The $3 d_{5 / 2}$ and $3 d_{3 / 2}$ peaks for the pure bulk Pd metal are located at 334.9 and $340.15 \mathrm{eV}$ [12]. The two peaks in $\mathrm{Pd}_{1} \mathrm{Co}_{1} / \mathrm{N}-\mathrm{rGO}$ are shifted positively compared with the standard bulk Pd metal. The positive shift in the binding energy of $\mathrm{Pd}$ is due to the modification of the electronic configuration of $\mathrm{Pd}$ atoms through the bimetallic interaction with cobalt and the electron transfer from the nitrogen atoms in the nitrogen-doped graphene oxide. Therefore, weak bond strength is expected for Pd with the reactive intermediate species, such as $\mathrm{CO}[28,35]$. In Figure 4E, the two strong deconvoluted Pd peaks show a small percentage of $\mathrm{Pd}(\mathrm{II})$, which may be retained in the sample because of the insufficient reduction of Pd precursors. However, this percentage is marginal, and most $\mathrm{Pd}$ remains in the metallic forms. Figure $4 \mathrm{D}$ shows the spectrum for $\mathrm{Co}$. This result confirms the presence of $\mathrm{Co}$ in the sample. The detailed surface composition of $\mathrm{Pd}_{1} \mathrm{CO}_{1} / \mathrm{N}-\mathrm{rGO}, \mathrm{Pd} / \mathrm{rGO}$, and $\mathrm{Pd}_{1} \mathrm{CO}_{1} / \mathrm{CNT}$ and its comparisons with the EDX results are presented in Table $\mathrm{S} 1$ in the supplementary material. 


\subsection{Electrochemical Evaluation}

\subsubsection{CO Stripping}

Carbon dioxide stripping was used to evaluate the resistance to $\mathrm{CO}$ poisoning and the ECSA of the as-synthesized electrocatalysts. CO is mainly generated during FAO as an intermediate in the indirect pathway. Growing evidence shows that $\mathrm{CO}$ is also produced in the direct pathway but as a reduction product of carbon dioxide and not as an intermediate. As a part of the process, $\mathrm{CO}$ should be removed immediately to maintain the electrocatalytic activity for FAO [36]. Therefore, oxidizing $\mathrm{CO}$ at a fast rate and a low potential is a prerequisite for an efficient and stable electrocatalyst. A CV scan in $0.5 \mathrm{H}_{2} \mathrm{SO}_{4}$ with a monolayer of pre-adsorbed $\mathrm{CO}$ on the Pd catalyst surface was conducted in the potential range of $-2-1 \mathrm{~V}$. Figure $5 \mathrm{~A}-\mathrm{D}$ shows the first two CV scans for the catalysts. In the first cycle, the characteristic hydrogen adsorption-desorption peaks are missing in the potential range of $-0.2-0$ because all the $\mathrm{Pd}$ active sites in the catalysts are occupied by $\mathrm{CO}$. The sharp oxidation peak at $0.4-0.8 \mathrm{~V}$ can be associated with $\mathrm{CO}$ oxidation [8,31]. In the reverse scan, the prominent peak at approximately $0.5 \mathrm{~V}$ is related to the reduction of $\mathrm{PdO}$ to $\mathrm{Pd}$. For the second scan, the characteristic hydrogen adsorption-desorption peaks in the range of $-0.2-0$ reappear, indicating that the monolayer of $\mathrm{CO}$ has been completely eliminated in the first scan. The peak and onset potentials are crucial parameters to compare the performance of the different catalysts. All the N-rGo-based catalysts show an onset potential of $0.41 \mathrm{~V}$ compared with the CNT-based catalysts $(0.51 \mathrm{~V})$. This negative shift of the onset potential in N-rGO clearly shows that the oxidation of CO is favored kinetically over the N-rGO compared with the CNT. However, the peak potential is more skewed toward a lower potential in the CNT. The electrochemical surface area for the catalysts was calculated using the following equation:

$$
\operatorname{ECSA}\left(\mathrm{cm}^{2} \mathrm{~g}^{-1}\right)=\frac{Q\left(\mu \mathrm{Ccm}^{-2}\right)}{m\left(\mathrm{gcm}^{-2}\right) \times 420 \mu \mathrm{Ccm}^{-2}},
$$

where $Q$ is the charge related to the CO desorption; $m$ is the Pd loading on the electrode; and $420 \mu \mathrm{Ccm}^{-2}$ is the charge required for the formation of a monolayer of $\mathrm{CO}$ adsorbed over Pd [15]. The calculated ECSA values are 16.05, 64.1, 17.32, 40.12, and $41.98 \mathrm{~m}^{2}$ $\mathrm{g}^{-1}$ for $\mathrm{Pd}_{3} \mathrm{Co} / \mathrm{N}-\mathrm{rGO}, \mathrm{Pd}_{1} \mathrm{Co}_{1} / \mathrm{N}-\mathrm{rGO}, \mathrm{PdCo}_{3} / \mathrm{N}-\mathrm{rGO}, \mathrm{Pd} / \mathrm{N}-\mathrm{rGO}$, and $\mathrm{Pd}_{1} \mathrm{Co}_{1} / \mathrm{CNT}$, respectively. The high value of ECSA for $\mathrm{Pd}_{1} \mathrm{Co}_{1} / \mathrm{N}-\mathrm{rGO}$ could be due to the formation of fine nanoparticles. The high estimate of ECSA for $\mathrm{Pd}_{1} \mathrm{Co}_{1} / \mathrm{N}-\mathrm{rGO}$ signals that it could be a potential catalyst for FAO.
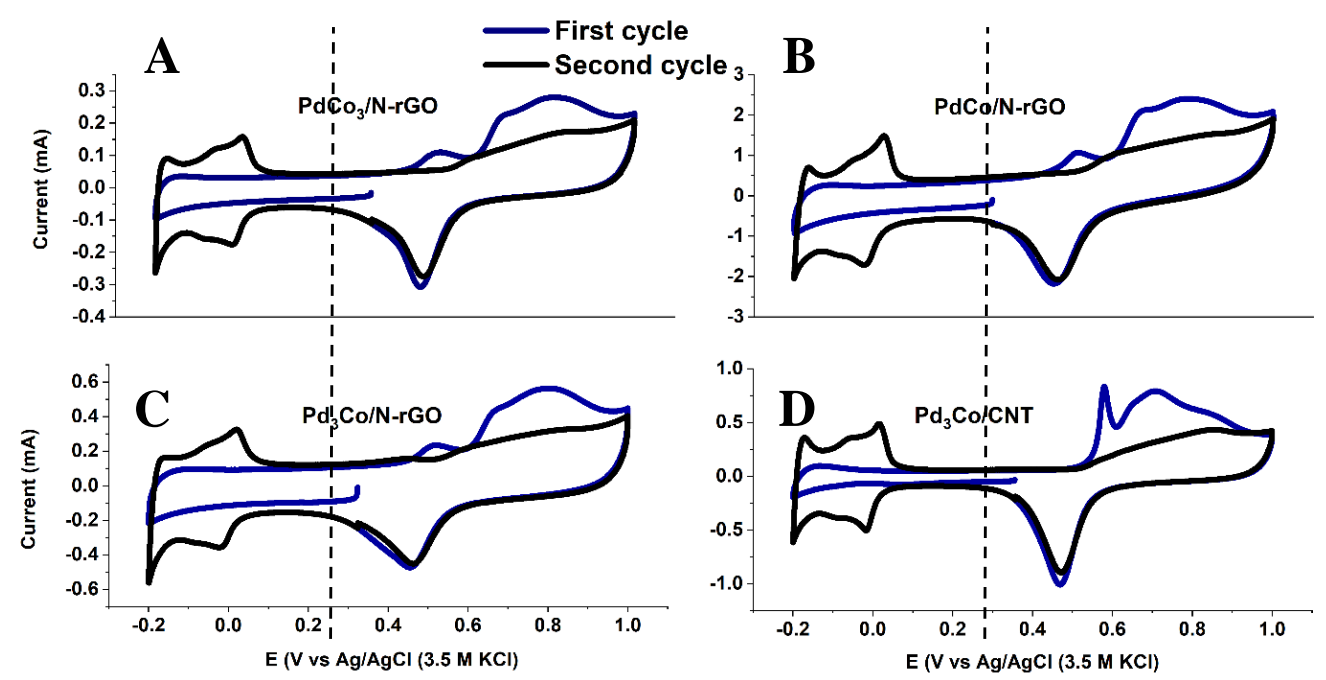

Figure 5. CO stripping voltammetry curves for (A) $\mathrm{PdCo}_{3} / \mathrm{N}-\mathrm{rGO}$, (B) $\mathrm{Pd}_{1} \mathrm{Co}_{1} / \mathrm{N}-\mathrm{rGO}$, (C) $\mathrm{Pd}_{3} \mathrm{Co} / \mathrm{N}-\mathrm{rGO}$, and (D) $\mathrm{Pd}_{1} \mathrm{Co}_{1} / \mathrm{CNT}$ in $0.5 \mathrm{M} \mathrm{H}_{2} \mathrm{SO}_{4}$ solution at a scan rate of $20 \mathrm{mv} \mathrm{s}^{-1}$. 


\subsubsection{Cyclic Voltammetry}

The electrocatalytic activity of the electrocatalysts can be confirmed and compared using CV. CV studies were carried out in a deaerated $0.5 \mathrm{M} \mathrm{H}_{2} \mathrm{SO}_{4}$ aqueous solution with and without formic acid in the potential range of $-0.2-1.2 \mathrm{~V}$ at a scan rate of $20 \mathrm{mV} \mathrm{s}^{-1}$ to determine the activity of the catalysts for FAO. Only the stable third cycles are reported here. The voltammograms are shown in Figure 6A,B. In the voltammogram of Figure 6A in $0.5 \mathrm{M} \mathrm{H}_{2} \mathrm{SO}_{4}$ only, the curves have three distinct areas of interest similar to the shapes reported elsewhere. In the forward scan at the low potential $(-0.2 \mathrm{~V}$ to $+0.1 \mathrm{~V})$ range, twin peaks are related to the adsorption-desorption of hydroxyl and oxygen species. In the region next to it, between $0.1 \mathrm{~V}$ and $0.5 \mathrm{~V}$, the current is almost constant and is called double-layer charging. Potentials higher than $0.5 \mathrm{~V}$ are due to the oxidation of Pd to make $\mathrm{PdO}$. In the reverse scan, one major peak associated with the reduction of $\mathrm{PdO}$ to $\mathrm{Pd}$ is observed at $0.45 \mathrm{~V}[27,29,37]$.
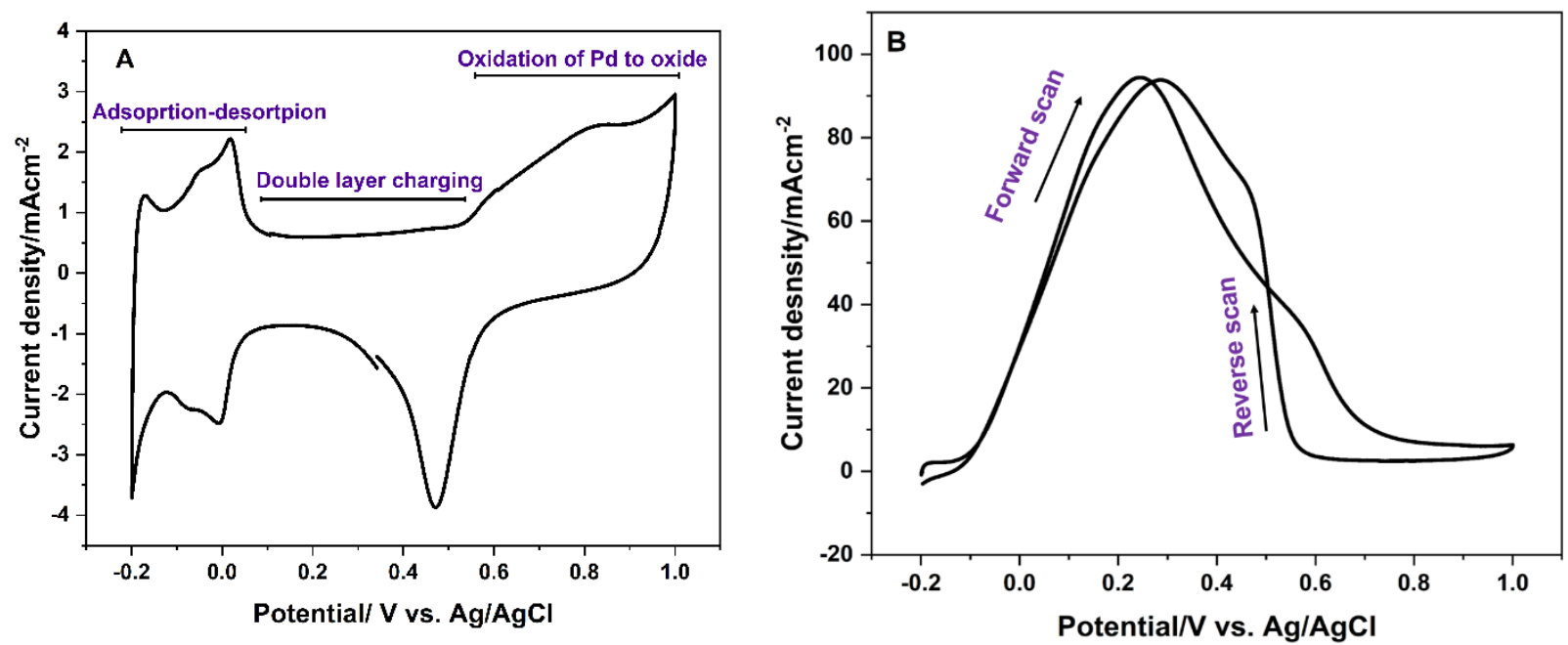

Figure 6. Cyclic voltammetry curves for $\mathrm{Pd}_{1} \mathrm{Co}_{1} / \mathrm{N}-\mathrm{rGO}$ in (A) $0.5 \mathrm{M} \mathrm{H}_{2} \mathrm{SO}_{4}$ solution and (B) $0.5 \mathrm{M} \mathrm{H}_{2} \mathrm{SO}_{4}+0.5 \mathrm{M} \mathrm{HCOOH}$ in solution at scan rate $20 \mathrm{mv} \mathrm{s}^{-1}$.

In the $0.5 \mathrm{M} \mathrm{H}_{2} \mathrm{SO}_{4}+0.5 \mathrm{HCOOH}$ aqueous solution, the nature of voltammograms in Figure $6 \mathrm{~B}$ is similar to those reported for Pd-based catalysts [27,31,38]. Entirely new features of the $\mathrm{CV}$ curve in $0.5 \mathrm{M} \mathrm{H} 2 \mathrm{SO} 4+0.5 \mathrm{HCOOH}$ with respect to the $\mathrm{CV}$ in $0.5 \mathrm{M} \mathrm{H}_{2} \mathrm{SO}_{4}$ aqueous solution are due to FAO. A small peak at around $-0.1 \mathrm{~V}$ is due to hydrogen desorption. A broad second and the most prominent peak is observed in the potential range of $0.1-0.5 \mathrm{~V}$. This peak is assigned to FAO via a direct pathway. Formic acid is adsorbed on the $\mathrm{Pd}$ and subsequently dissociates directly to carbon dioxide in the direct pathway. In addition, a shoulder peak at a higher potential could be related to the FAO via an indirect pathway [7,36]. Cobalt is not active for FAO [16,18]. Additional features of the $\mathrm{CV}$ in Figure $6 \mathrm{~B}$ show that $\mathrm{Pd}_{1} \mathrm{Co}_{1} / \mathrm{N}-\mathrm{rGO}$ is active for FAO. Therefore, all the activity for FAO is contributed by the Pd nanoparticles. A large peak in the reverse scan could be due to the oxidation of formic acid and poisonous species at the Pd surface, regenerated from the reduction of $\mathrm{PdO}$ formed in the forward scan, indicating the improved tolerance toward catalyst deactivation $[12,16]$. The peak position and the mass activity associated with the peak are used to compare the efficiency of the catalysts.

$\mathrm{CV}$ curves for the as-prepared $\mathrm{Pd}_{\mathrm{x}} \mathrm{Co}_{\mathrm{y}} / \mathrm{N}-\mathrm{rGO}$ (x:y = 1:1, 3:1, and 1:3), Pd/N-rGO, and $\mathrm{Pd}_{1} \mathrm{Co}_{1} / \mathrm{CNT}$ were generated in $0.5 \mathrm{H}_{2} \mathrm{SO}_{4}+0.5 \mathrm{M} \mathrm{HCOOH}$ in the range of $-0.2-1.2 \mathrm{~V}$ at a scan rate of $20 \mathrm{mv} \mathrm{s}^{-1}$. The current was normalized to the actual mass of the $\mathrm{Pd}$ to compare the efficacy of the catalysts. All the electrocatalysts show a similar nature of curves as described earlier. The peak current density for all the catalysts is shown in Figure 7B. The ECSA and the corresponding peak current density for the forward and the reverse 
peaks are summarized in Table 2. $\mathrm{Pd}_{1} \mathrm{Co}_{1} / \mathrm{N}$-rGO displays the highest current output of $4833.12 \mathrm{~mA} \mathrm{mg}^{-1}$. This current density is almost 10 times higher than that of Pd/N-rGO.
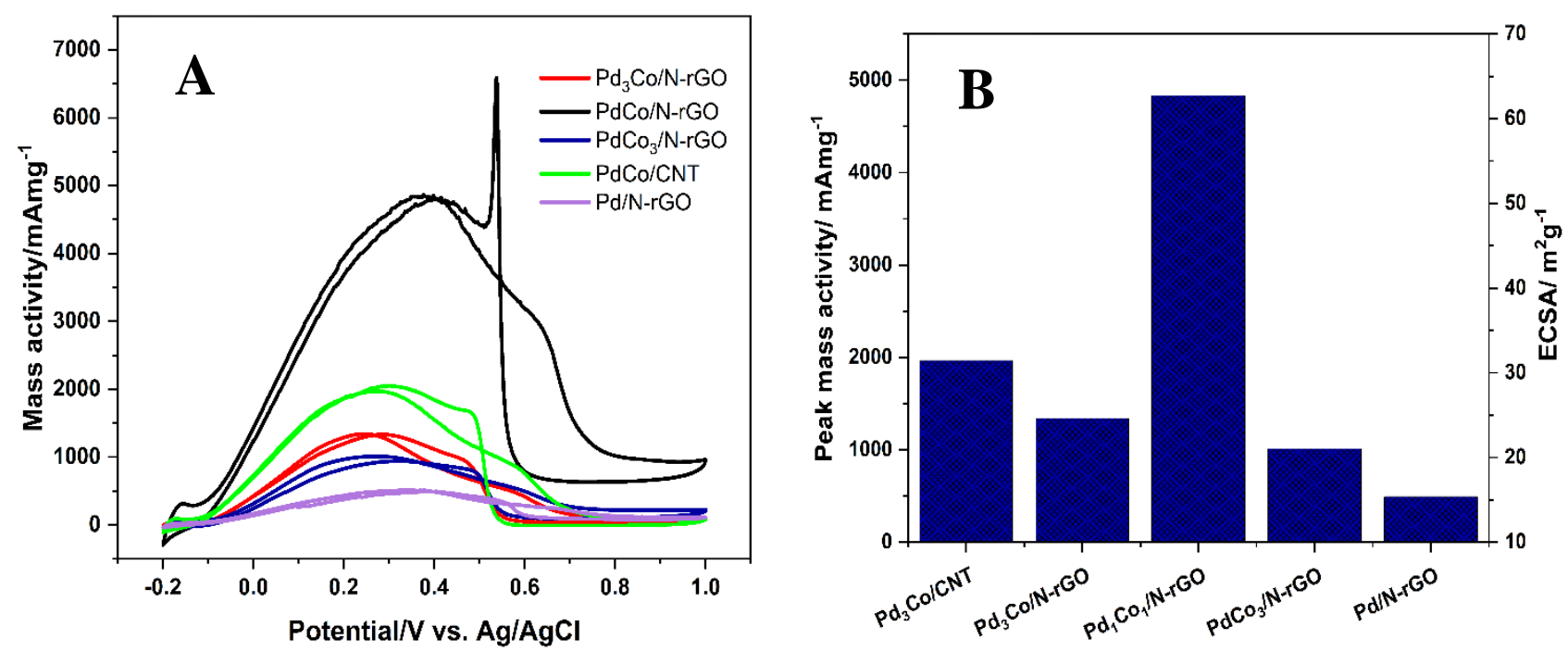

Figure 7. (A) Cyclic voltammetry (CV) for the catalysts in $0.5 \mathrm{M} \mathrm{H}_{2} \mathrm{SO}_{4}$ and $0.5 \mathrm{M} \mathrm{HCOOH}$ solutions at a scan rate of $20 \mathrm{mv}$ $\mathrm{s}^{-1}$ at room temperature (B) peak mass activity for the as-prepared catalysts in the CV scan.

Table 2. Electrochemical performance of the as-prepared catalysts.

\begin{tabular}{|c|c|c|c|c|}
\hline Catalyst & $\begin{array}{c}\text { ECSA } \\
\left(\mathrm{m}^{2} \mathrm{~g}^{-1}\right)\end{array}$ & $\begin{array}{l}\text { Peak Potential } \\
\text { (V vs. Ag/AgCl) } \\
\quad(3 \mathrm{M} \mathrm{KCl})\end{array}$ & $\begin{array}{c}\text { Peak Mass } \\
\text { Activity } \\
\text { (Forward Scan) } \\
\left(\mathbf{m A ~ m g} \mathbf{~ m}^{-1} \text { ) }\right.\end{array}$ & $\begin{array}{c}\text { Peak Mass Activity } \\
\text { (Backward Scan) } \\
\left(\mathrm{mA} \mathrm{mg} \mathbf{~ m}^{-1}\right)\end{array}$ \\
\hline $\mathrm{Pd}_{3} \mathrm{Co} / \mathrm{CNT}$ & 41.98 & 0.26 & 1964 & 2046 \\
\hline $\mathrm{Pd}_{3} \mathrm{Co} / \mathrm{N}-\mathrm{rGO}$ & 16.05 & 0.248 & 1340 & 1330 \\
\hline $\mathrm{Pd}_{1} \mathrm{Co}_{1} / \mathrm{N}-\mathrm{rGO}$ & 64.10 & 0.36 & 4833 & 6584 \\
\hline $\mathrm{PdCo}_{3} / \mathrm{N}-\mathrm{rGO}$ & 17.32 & 0.26 & 1010 & 1008 \\
\hline $\mathrm{Pd} / \mathrm{N}-\mathrm{rGO}$ & 40.12 & 0.39 & 491 & 490 \\
\hline
\end{tabular}

Moreover, the mass activity values reported here exceed the values reported recently in the literature (Table 3). First, cobalt is an excellent adatom that improves the Pd dispersion and modifies the electronic structure of the Pd metal. The addition of $\mathrm{Co}$ in the $\mathrm{Pd} / \mathrm{N}$ reduced graphene oxide catalyst improves the performance. Cobalt can facilitate $\mathrm{CO}$ oxidation from the Pd surface through a well-known bifunctional effect [39]. As per other XPS analyses presented in several reports, Co modifies the electronic structure of $\mathrm{Pd}$ that results in the downshift of the d-orbitals in PdCo nanoparticles relative to $\mathrm{Pd} / \mathrm{C}$ that may result in the weakened adsorption of the CO-like species [16]. The atomic ratio of $\mathrm{Pd}$ and the adatom is an important parameter that has a profound effect on the electrocatalytic performance of the bimetallic catalysts. The occurrence of the highest activity was obtained for $\mathrm{Pd}_{1} \mathrm{Co}_{1} / \mathrm{N}$-rGO. Lui et al. tested PdCo with different atomic ratios and showed that $\mathrm{Pd}_{1} \mathrm{CO}_{1}$ obtains the highest current density and stability [16]. In our case, the highest activity is due to the presence of sufficient Co to modify the d-orbital characteristic of $\mathrm{Pd}$ atoms because an excessive amount hinders the formation of Pd active sites. An optimum amount of cobalt is essential to reap the benefits of a bimetallic catalyst, which in our case is equimolar. 
Table 3. Comparison of the ECSA and mass activity for the as-prepared catalysts with the reported literature values under identical test conditions.

\begin{tabular}{|c|c|c|c|c|c|}
\hline $\begin{array}{l}\text { Serial } \\
\text { Number }\end{array}$ & Catalyst & $\begin{array}{c}\text { ECSA } \\
\left(\mathrm{m}^{2} \mathrm{~g}^{-1}\right)\end{array}$ & $\begin{array}{l}\text { Forward Peak } \\
\text { (Mass Activity } \\
\left(\mathrm{mA} \mathrm{mg}^{-1}\right)\end{array}$ & $\begin{array}{l}\text { Forward Peak (ECSA } \\
\text { Normalized) }\left(\mathrm{A} \mathrm{m}^{-2}\right)\end{array}$ & Reference \\
\hline 1 & $\begin{array}{l}\text { Pd black } \\
\text { (Johnson } \\
\text { Matthey) }\end{array}$ & 17.80 & 120 & 6.74 & $\begin{array}{l}\text { Ma et al. } \\
\text { [40] }\end{array}$ \\
\hline 2 & PdPt NC & 285 & 1000 & 3.51 & $\begin{array}{l}\text { Bhalothia } \\
\text { et al. [41] }\end{array}$ \\
\hline 3 & $\begin{array}{c}\mathrm{SnO}_{2^{-}} \\
\text {decorated Pd } \\
\text { nanocubes }\end{array}$ & - & 2460 & - & $\begin{array}{l}\text { Rettenmaier } \\
\text { et al. [42] }\end{array}$ \\
\hline 4 & $\mathrm{PdCo} / \mathrm{CNF}$ & 45.03 & 1500 & 33.31 & $\begin{array}{l}\text { Lui et al. } \\
\text { [16] }\end{array}$ \\
\hline 5 & $\mathrm{Pd} / \mathrm{C}$ & 43.86 & 456 & 10.40 & $\begin{array}{l}\text { Lui et al. } \\
\text { [16] }\end{array}$ \\
\hline 6 & $\mathrm{Pd} / \mathrm{NS}-\mathrm{G}$ & 83.40 & 501 & 6.01 & $\begin{array}{c}\text { Zhang et al. } \\
\text { [43] }\end{array}$ \\
\hline 7 & $\begin{array}{l}\mathrm{Pd}_{3} \mathrm{Fe} / \mathrm{N}- \\
\quad \mathrm{rGO}\end{array}$ & 65.30 & 1463 & 22.40 & $\begin{array}{l}\text { Hossain } \\
\text { et al. [12] }\end{array}$ \\
\hline 8 & $\begin{array}{c}\mathrm{Pd}_{75} \mathrm{Cu}_{25} / \mathrm{N}- \\
\mathrm{rGO}\end{array}$ & 73.39 & 1738 & 23.68 & $\begin{array}{l}\text { Chowdhury } \\
\text { et al. [27] }\end{array}$ \\
\hline 9 & $\begin{array}{l}\mathrm{Pd}_{1} \mathrm{Co}_{1} / \mathrm{N}- \\
\mathrm{rGO}\end{array}$ & 64.10 & 4833 & 75.40 & This work \\
\hline
\end{tabular}

The effect of support materials was compared by comparing the catalytic activity of PdCo supported on N-rGO and CNT prepared by following the same procedure. The nature of the $\mathrm{CV}$ in both cases is similar. However, the peak current density for $\mathrm{Pd}_{1} \mathrm{Co}_{1} / \mathrm{CNT}$ is 1964.76 vs. $4833.12 \mathrm{~mA} \mathrm{mg}{ }^{-1} \mathrm{Pd}$ for $\mathrm{Pd}_{1} \mathrm{Co}_{1} / \mathrm{N}-\mathrm{rGO}$. This high activity for $\mathrm{Pd}_{1} \mathrm{Co}_{1} / \mathrm{N}-\mathrm{rGO}$ is ascribed to the extraordinary morphological and electronic properties of nitrogen-doped graphene oxide. The nitrogen atom in N-rGO can function as an electron-rich center. The electron-rich center can donate an electron to Pd to increase its electron density, which can modify the adsorption characteristics of the Pd for the formic acid and intermediates. Moreover, a secondary but important feature that helps is the large surface area and pore volume of graphene. Cazaras-Avila et al. compared the performance of OMC and multi-walled CNT as support materials. The higher performance of PdCo over OMC is ascribed to the combination of the mesoporous structure of the support, which promotes the catalyst-support interaction facilitating the mass transfer process during the reaction, and to the incorporation of $\mathrm{Co}$ in the Pd structure [17]. The current densities normalized to the ECSA are presented in Table 3 to investigate the factors other than the particle size effect responsible for the catalytic activity enhancement in $\mathrm{Pd}_{1} \mathrm{Co}_{1} / \mathrm{N}-\mathrm{rGO}$. The current densities normalized to the ECSA value reported here for $\mathrm{Pd}_{1} \mathrm{Co}_{1} / \mathrm{N}-\mathrm{rGO}$ are higher than the literature values in Table 3 and are more than 10 times higher than the commercial Pd black catalyst. This observation suggests that the enhancement in the catalytic activity cannot be ascribed totally to the particle size effect. The bifunctional mechanism imparted by $\mathrm{Co}$ and the electronic modification resulting from the nitrogen containing graphene oxide support material are far more critical factors for the enhancement of the catalytic activity of $\mathrm{Pd}_{1} \mathrm{Co}_{1} / \mathrm{N}-\mathrm{rGO}$.

\subsubsection{Chronoamperometry Analysis}

Long-term stability is an essential aspect for the practical implementation of the catalysts for fuel cells. CA is a valuable technique to determine the long-term stability of the catalyst in an acidic environment. Figure 8 displays the CA curves performed in $0.5 \mathrm{M}$ $\mathrm{H}_{2} \mathrm{SO}_{4}+0.5 \mathrm{M} \mathrm{HCOOH}$ solution at $0.3 \mathrm{~V}$ for $5000 \mathrm{~s}$. The nature of the curves is similar to earlier reports $[7,29]$. The curves mainly consist of an initial rapid decrease in current due 
to double-layer charging, followed by a gradual decay signaling, which slows down the deactivation of the catalysts by $\mathrm{CO}$. The origin of the $\mathrm{CO}$ poisoning for Pd-based catalysts is confusing because FAO occurs via a direct method on $\mathrm{Pd}$, which does not produce $\mathrm{CO}$ as an intermediate. Among many contradicting hypotheses, Wang et al. proposed that $\mathrm{CO}$ is generated by the reduction in carbon dioxide [36]. Carbon dioxide is the ultimate product of FAO. The steady-state value of the current after $5000 \mathrm{~s}$ is used to compare the stability of the catalysts. $\mathrm{Pd}_{1} \mathrm{Co}_{1} / \mathrm{N}-\mathrm{rGO}$ showed the highest steady-state current of $700 \mathrm{~mA} \mathrm{mg}{ }^{-1}$ $\mathrm{Pd}$, which is 2.3 and 6 times compared with those of $\mathrm{Pd}_{1} \mathrm{Co}_{1} / \mathrm{CNT}$. These results show that nitrogen-doped reduced graphene oxide is an excellent support material and that an equimolar bimetallic PdCo is the optimum composition for the PdCo bimetallic catalyst.

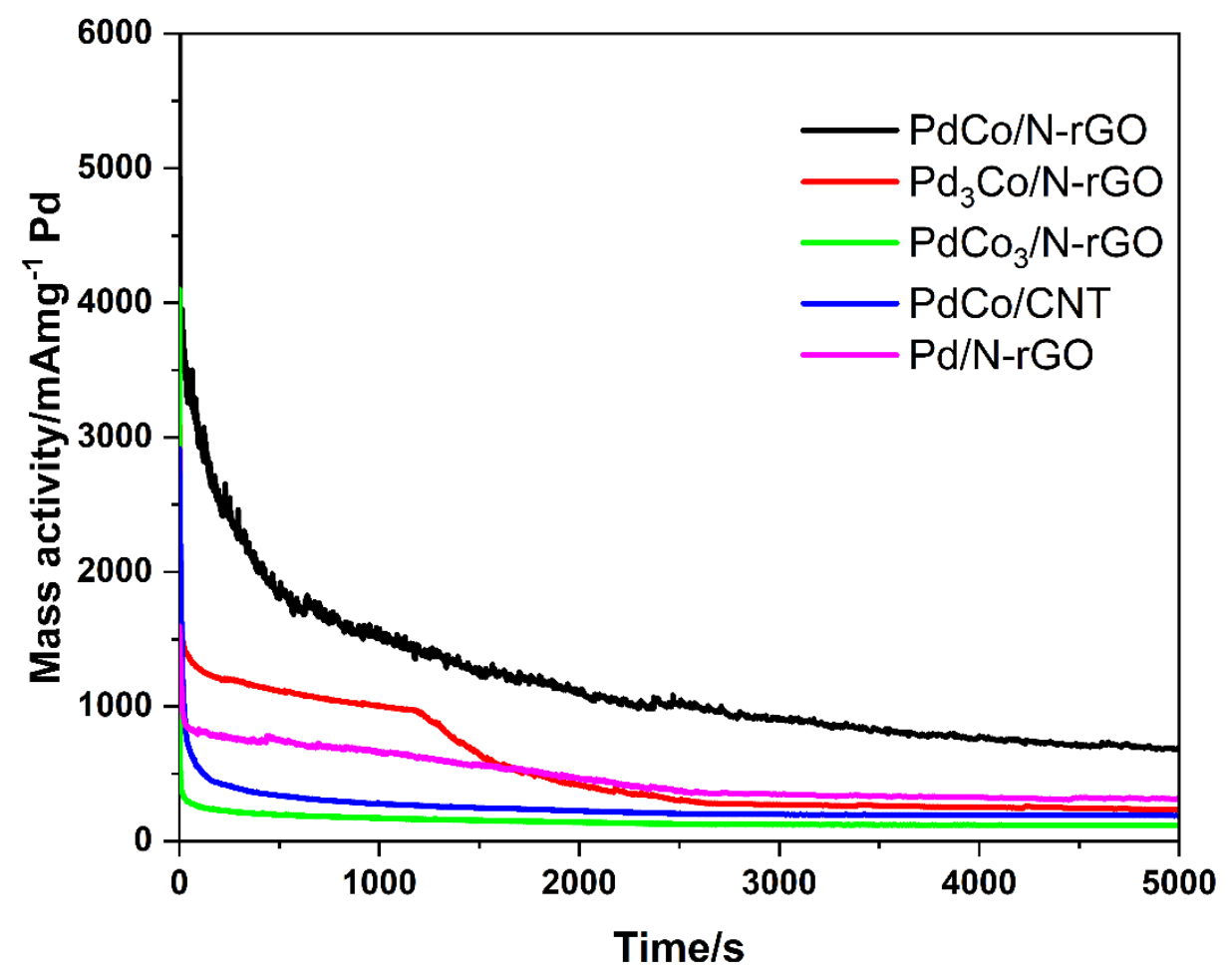

Figure 8. Chronoamperometry of the catalysts in $0.5 \mathrm{M} \mathrm{H}_{2} \mathrm{SO}_{4}$ and $0.5 \mathrm{M} \mathrm{HCOOH}$ solutions at $0.35 \mathrm{~V}$ for the catalysts after $5000 \mathrm{~s}$.

The excellent performance of $\mathrm{Pd}_{1} \mathrm{Co}_{1} / \mathrm{N}-\mathrm{rGO}$ arises from the bimetallic effect of $\mathrm{Co}$ and nitrogen-doped graphene. Lui et al. found a similar case where PdCo shows very high current density [16]. Morales-Acosta et al. reported a similar finding [30].

\section{Experimental}

\subsection{Chemicals}

Sulfuric, hydrochloric, and formic acid; GO flakes; Nafion solution; and isopropanol were supplied by Sigma Adrich. Multiwall CNTs with 99.99\% purity were provided by Cheap Tubes. All the remaining chemicals, including urea, sodium citrate dihydrate, and sodium borohydride were purchased from Merck and were of research grade. All the gases were high purity $(99.999 \%)$ and purchased from Linde-SIGAS. Deionized water $(18.2 \mathrm{M} \Omega \mathrm{cm})$ used for synthesis and electrochemical experiments was supplied by Millipore Q Academic system.

\subsection{Catalyst Preparation}

\subsubsection{Preparation of Nitrogen-Doped Reduced Graphene Oxide}

Nitrogen-doped graphene oxide was synthesized using the hydrothermal method with urea as a nitrogen source. A similar methodology was employed in our previously 
published paper [12]. Ammonia is a preferred nitrogen source and reducing agent because it is safer and cheaper and more facile than hydrazine hydrate and other reagents. For the pretreatment of pristine GO flakes before nitrogen doping, $100 \mathrm{mg}$ of GO flakes were sonicated in $250 \mathrm{~mL}$ of deionized water for $2 \mathrm{~h}$ to exfoliate the layers of individual GO flakes. The black solid material was recovered by centrifuging and then dried in a vacuum oven for $5 \mathrm{~h}$ at $70{ }^{\circ} \mathrm{C}$. The pretreated GO flakes $(100 \mathrm{mg})$ were suspended in $250 \mathrm{~mL}$ of deionized water, and then $50 \mathrm{~mL}$ of $32 \%$ ammonia solution were added to it. A $5 \%$ (by volume) aqueous $\mathrm{HCl}$ solution was used to adjust the $\mathrm{pH}$ of the suspension to nearly 8 . The suspension was sonicated for $2 \mathrm{~h}$ before transferring to a Teflon-lined $500 \mathrm{~mL}$ steel hydrothermal reactor. Then, the hydrothermal reactor was slowly heated up to $220^{\circ} \mathrm{C}$ at a rate of $2{ }^{\circ} \mathrm{C} / \mathrm{min}$ in a muffle furnace and then maintained at $220^{\circ} \mathrm{C}$ for $8 \mathrm{~h}$. The reactor was allowed to cool to room temperature naturally. The black residue was recovered from the suspension using a high-speed centrifuge (Thermo Fisher Scientific Inc., New York, NY, USA) operated at $5000 \mathrm{rpm}$ and washed copiously with water until the washing solution turned near neutral. Finally, the material was vacuum dried at $80^{\circ} \mathrm{C}$ for $12 \mathrm{~h}$ to obtain the final nitrogen-doped reduced graphene oxide.

\subsubsection{Synthesis of N-Reduced Graphene Oxide Supported PdCo Nanoparticles}

The $\mathrm{Pd}_{\mathrm{x}} \mathrm{Co}_{\mathrm{y}}$ nanoparticles were deposited on the as-prepared support $\mathrm{N}-\mathrm{rGO}$ by using the wet impregnation-reduction method with sodium citrate dihydrate as a stabilizing agent. Cobalt nitrate and palladium nitrates were used as precursors for $\mathrm{Co}$ and $\mathrm{Pd}$ nanoparticles, respectively. The detailed synthesis route has been described by Zhou et al. [44]. In short, the precursor solution(s) was added dropwise in the suspension of $\mathrm{N}$-rGO in water prepared by sonicating $100 \mathrm{mg}$ of N-rGO in $250 \mathrm{~mL}$ of deionized water. The solution was made slightly alkaline $(\mathrm{pH} 8)$ by adding a few drops of $0.5 \mathrm{M} \mathrm{NaOH}$ aqueous solution. To this suspension, stabilizing agent sodium citrate dihydrate was added. A freshly prepared aqueous solution of sodium borohydride was added to the suspension dropwise, and the suspension was stirred overnight to complete the reduction process. Finally, the nanoparticles were recovered by centrifuging, washed with water, and then vacuum dried to obtain $\mathrm{Pd}_{\mathrm{x}} \mathrm{Co}_{\mathrm{y}} / \mathrm{N}-\mathrm{rGO}$ powder. Finally, $100 \mathrm{mg}$ of the catalyst were heat treated at $450 \mathrm{C}$ in $5 \mathrm{vol} \%$ hydrogen gas (balance high purity nitrogen) in a vaccum furnace (Thermcraft Inc., Sacramento, CA, USA) to induce alloy formation. For comparison, $\mathrm{Pd} / \mathrm{N}-\mathrm{rGO}$ and $\mathrm{Pd}_{1} \mathrm{Co}_{1} / \mathrm{CNT}$ were prepared using the method outlined earlier. The metal content in all the synthesized catalysts was maintained at $20 \mathrm{wt} \%$.

\subsection{Catalyst Characterizations}

XRD patterns were obtained using Bruker $\mathrm{D} 8$ with $\mathrm{Cu} \mathrm{K}$ alpha as a radiation source operating at $40 \mathrm{kV}$ and $40 \mathrm{~mA}$. Diffraction patterns were obtained in the range of $10-90^{\circ}$ at a scan rate of $5^{\circ} / \mathrm{min}$. SEM (JEOL 7800) coupled with EDX was used to study morphology and obtain the elemental composition of the catalysts. TEM was performed using FEI Talos F200X supplied by Thermo Scientific to ascertain the chemical composition of the catalysts. X-ray spectroscopy of selected samples was performed using ESCALABZ 50 supplied by Thermo scientific to identify the composition and electronic structure of the chemical species.

\subsection{Electrochemical Measurements}

The electrocatalytic activity of the as-prepared catalysts was measured through CV, CO stripping voltammetry, and CA in a homemade three-cell electrochemical cell using a potentiostat-galvanostat (Biologic S300, Seyssinet-Pariset, France). A catalyst-coated glassy carbon electrode (diameter $3 \mathrm{~cm}$ ) was used as a working electrode. A highly polished platinum plate $\left(8 \mathrm{~cm}^{2}\right)$ and a $\mathrm{Ag} / \mathrm{AgCl}$ electrode were used as the counter and reference electrodes, respectively. $\mathrm{CV}$ was carried out in the potential range of $-2-1.2 \mathrm{~V}$ with a scan rate of $20 \mathrm{mv} \mathrm{s}^{-1}$ in an aqueous solution of $0.5 \mathrm{M} \mathrm{H}_{2} \mathrm{SO} 4+0.5 \mathrm{M} \mathrm{HCOOH}$. The solution was deaerated using high-purity nitrogen $(99.99 \%)$ before the experiments. CO stripping 
$\mathrm{CV}$ was carried out by varying the voltage from $-0.2 \mathrm{~V}$ to $1.2 \mathrm{~V}$ at a scan rate of $20 \mathrm{mv} \mathrm{s}^{-1}$ in $0.5 \mathrm{M} \mathrm{H}_{2} \mathrm{SO}_{4}$ with a pre-adsorbed monolayer of $\mathrm{CO}$ on the catalysts. The preparation method for a pre-adsorbed CO monolayer is available in the study by Zhou et al. [30]. CA was conducted for $5000 \mathrm{~s}$ by measuring the output current by maintaining the potential at $+0.3 \mathrm{~V}$.

The catalyst-coated glassy carbon electrode was prepared by coating the catalyst ink prepared by ultra sonicating $10 \mathrm{mg}$ of the catalysts in $500 \mu \mathrm{mL}$ of Nafion solution for approximately $1 \mathrm{~h}$. Drops of the ink were transferred to the previously polished GC electrode and then air dried.

\section{Conclusions}

Palladium and cobalt alloy nanoparticles with different atomic ratios were supported on nitrogen-doped reduced graphene oxide. Nitrogen-doped reduced graphene oxide was prepared by the hydrothermal treatment of graphene oxide with urea. TEM and SEM analyses showed that PdCo nanoparticles are evenly anchored on the support material via impregnation and reduction using sodium borohydride. XPS analysis confirmed the presence of different species of nitrogen and a positive shift in the Pd binding energy. The as-prepared catalysts show excellent activity for the FAO reaction. Among all the catalysts, $\mathrm{Pd}_{1} \mathrm{Co}_{1} / \mathrm{N}-\mathrm{rGO}$ shows the highest ECSA and mass activity. The best performance of $\mathrm{Pd}_{1} \mathrm{Co}_{1} / \mathrm{N}-\mathrm{rGO}$ can be ascribed to the formation of small $(3.65 \mathrm{~nm})$ nanoparticles and a bifunctional effect by $\mathrm{Co}$. The support nitrogen-doped reduced graphene oxide provides a strong metal-support interaction, additional active metal sites, and more robust anchoring of the metal nanoparticles.

Supplementary Materials: The following are available online at https:/ /www.mdpi.com/article/10 .3390/catal11080910/s1, Table S1: Composition of the catalysts by XPS and EDX (atomic percentage).

Author Contributions: Conceptualization, S.S.H. and J.S.; funding acquisition, S.S.H.; methodology, H.T.A.-H., M.M.A. and S.S.A.; catalyst characterization, J.S. and S.M.; data curation, M.M.A. and S.S.H.; Writing—Original Draft Preparation, M.M.A., S.S.H., H.T.A.-H. and S.S.A.; writing-review and editing, G.M. and S.S.H. All authors have read and agreed to the published version of the manuscript.

Funding: The authors acknolwdge the Deanship of Scientific Research at King Faisal University for the financial support under Nasher Track (Grant No.206165).

Data Availability Statement: The data presented in this study are available in the article.

Acknowledgments: The authors would like to acknowledge the contribution of the Core Labs group at the Qatar Environment and Energy Research Institute, Hamad Bin Khalifa University, Qatar Foundation, especially: Akshath Raghu Shetty for XRD, Yahya Zakaria for XPS, Mohamed I. Helal, and Mujaheed Pasha for SEM and TEM characterizations.

Conflicts of Interest: The authors declare that we have no conflict of interest. All authors have seen and approved the manuscript being submitted. We warrant that the article is the authors' original work. We warrant that the article has not received prior publication and is not under consideration for publication elsewhere.

\section{References}

1. Yuan, X.-Z.; Nayoze-Coynel, C.; Shaigan, N.; Fisher, D.; Zhao, N.; Zamel, N.; Gazdzicki, P.; Ulsh, M.; Friedrich, K.A.; Girard, F.; et al. A review of functions, attributes, properties and measurements for the quality control of proton exchange membrane fuel cell components. J. Power Sources 2021, 491, 229540. [CrossRef]

2. Jeerh, G.; Zhang, M.; Tao, S. Recent progress in ammonia fuel cells and their potential applications. J. Mater. Chem. A 2021, 9 , 727-752. [CrossRef]

3. Ma, Z.; Legrand, U.; Pahija, E.; Tavares, J.R.; Boffito, D.C. From $\mathrm{CO}_{2}$ to Formic Acid Fuel Cells. Ind. Eng. Chem. Res. 2021, 60, 803-815. [CrossRef]

4. Chatterjee, S.; Dutta, I.; Lum, Y.; Lai, Z.; Huang, K.-W. Enabling storage and utilization of low-carbon electricity: Power to formic acid. Energy Environ. Sci. 2021, 14, 1194-1246. [CrossRef] 
5. Uhm, S.; Lee, H.J.; Lee, J. Understanding underlying processes in formic acid fuel cells. Phys. Chem. Chem. Phys. 2009, 11, 9326-9336. [CrossRef]

6. Fang, Z.; Chen, W. Recent advances in formic acid electro-oxidation: From the fundamental mechanism to electrocatalysts. Nanoscale Adv. 2021, 3, 94-105. [CrossRef]

7. Cuesta, A.; Cabello, G.; Osawa, M.; Gutiérrez, C. Mechanism of the Electrocatalytic Oxidation of Formic Acid on Metals. ACS Catal. 2012, 2, 728-738. [CrossRef]

8. Jiang, K.; Zhang, H.-X.; Zou, S.; Cai, W.-B. Electrocatalysis of formic acid on palladium and platinum surfaces: From fundamental mechanisms to fuel cell applications. Phys. Chem. Chem. Phys. 2014, 16, 20360-20376. [CrossRef]

9. Meng, H.; Zeng, D.; Xie, F. Recent Development of Pd-Based Electrocatalysts for Proton Exchange Membrane Fuel Cells. Catalysts 2015, 5, 1221-1274. [CrossRef]

10. Shen, T.; Zhang, J.; Chen, K.; Deng, S.; Wang, D. Recent Progress of Palladium-Based Electrocatalysts for the Formic Acid Oxidation Reaction. Energy Fuels 2020, 34, 9137-9153. [CrossRef]

11. Ejikeme, P.M.; Makgopa, K.; Ozoemena, K.I. Effects of Catalyst-Support Materials on the Performance of Fuel Cells. In Nanomaterials for Fuel Cell Catalysis; Ozoemena, K.I., Chen, S., Eds.; Springer International Publishing: Cham, Switzerland, 2016; pp. 517-550. [CrossRef]

12. Hossain, S.K.S. Bimetallic Pd-Fe Supported on Nitrogen-Doped Reduced Graphene Oxide as Electrocatalyst for Formic Acid Oxidation. Arab. J. Sci. Eng. 2021, 46, 6543-6556. [CrossRef]

13. Samad, S.; Loh, K.S.; Wong, W.Y.; Lee, T.K.; Sunarso, J.; Chong, S.T.; Wan Daud, W.R. Carbon and non-carbon support materials for platinum-based catalysts in fuel cells. Int. J. Hydrog. Energy 2018, 43, 7823-7854. [CrossRef]

14. Mazurkiewicz-Pawlicka, M.; Malolepszy, A.; Mikolajczuk-Zychora, A.; Mierzwa, B.; Borodzinski, A.; Stobinski, L. A simple method for enhancing the catalytic activity of Pd deposited on carbon nanotubes used in direct formic acid fuel cells. Appl. Surf. Sci. 2019, 476, 806-814. [CrossRef]

15. Morales-Acosta, D.; Ledesma-Garcia, J.; Godinez, L.A.; Rodríguez, H.G.; Álvarez-Contreras, L.; Arriaga, L.G. Development of Pd and Pd-Co catalysts supported on multi-walled carbon nanotubes for formic acid oxidation. J. Power Sources 2010, 195, 461-465. [CrossRef]

16. Liu, D.; Guo, Q.; Hou, H.; Niwa, O.; You, T. Pd $\mathrm{Co}_{\mathrm{y}}$ Nanoparticle/Carbon Nanofiber Composites with Enhanced Electrocatalytic Properties. ACS Catal. 2014, 4, 1825-1829. [CrossRef]

17. Cazares-Ávila, E.; Ruiz-Ruiz, E.J.; Hernández-Ramírez, A.; Rodríguez-Varela, F.J.; Morales-Acosta, M.D.; Morales-Acosta, D. Effect of OMC and MWNTC support on mass activity of PdCo catalyst for formic acid electro-oxidation. Int. J. Hydrog. Energy 2017, 42, 30349-30358. [CrossRef]

18. Shafaei Douk, A.; Saravani, H.; Noroozifar, M. A fast method to prepare Pd-Co nanostructures decorated on graphene as excellent electrocatalyst toward formic acid oxidation. J. Alloys Compd. 2018, 739, 882-891. [CrossRef]

19. Ahmad, K.N.; Noor Azam, A.M.I.; Isahak, W.N.R.W.; Mohd Zainoodin, A.; Masdar, M.S. Improving the electrocatalytic activity for formic acid oxidation of bimetallic Ir-Zn nanoparticles decorated on graphene nanoplatelets. Mater. Res. Express 2020, 7, 015095. [CrossRef]

20. Olabi, A.G.; Abdelkareem, M.A.; Wilberforce, T.; Sayed, E.T. Application of graphene in energy storage device-A review. Renew. Sustain. Energy Rev. 2021, 135, 110026. [CrossRef]

21. Kumar, R.; Sahoo, S.; Joanni, E.; Singh, R.K.; Maegawa, K.; Tan, W.K.; Kawamura, G.; Kar, K.K.; Matsuda, A. Heteroatom doped graphene engineering for energy storage and conversion. Mater. Today 2020, 39, 47-65. [CrossRef]

22. Ullah, S.; Shi, Q.; Zhou, J.; Yang, X.; Ta, H.Q.; Hasan, M.; Ahmad, N.M.; Fu, L.; Bachmatiuk, A.; Rümmeli, M.H. Advances and Trends in Chemically Doped Graphene. Adv. Mater. Interfaces 2020, 7, 2000999. [CrossRef]

23. Wang, H.; Maiyalagan, T.; Wang, X. Review on Recent Progress in Nitrogen-Doped Graphene: Synthesis, Characterization, and Its Potential Applications. ACS Catal. 2012, 2, 781-794. [CrossRef]

24. Xu, H.; Ma, L.; Jin, Z. Nitrogen-doped graphene: Synthesis, characterizations and energy applications. J. Energy Chem. 2018, 27, 146-160. [CrossRef]

25. Shao, Y.; Zhang, S.; Engelhard, M.H.; Li, G.; Shao, G.; Wang, Y.; Liu, J.; Aksay, I.A.; Lin, Y. Nitrogen-doped graphene and its electrochemical applications. J. Mater. Chem. 2010, 20, 7491-7496. [CrossRef]

26. Hossain, S.S. Heteroatom-Doped Carbon Materials as Support for Anode Electrocatalysts for Direct Formic Acid Fuel Cells. Int. J. Electrochem. Sci 2021, 16, 150926. [CrossRef]

27. Chowdhury, S.R.; Maiyalagan, T. Enhanced Electro-catalytic Activity of Nitrogen-doped Reduced Graphene Oxide Supported PdCu Nanoparticles for Formic Acid Electro-oxidation. Int. J. Hydrog. Energy 2019, 44, 14808-14819. [CrossRef]

28. Sun, Y.; Zhou, T.; Pan, Q.; Zhang, X.; Guo, J. PtFe/nitrogen-doped graphene for high-performance electrooxidation of formic acid with composition sensitive electrocatalytic activity. RSC Adv. 2015, 5, 60237-60245. [CrossRef]

29. Juárez-Marmolejo, L.; Pérez-Rodríguez, S.; Montes de Oca-Yemha, M.G.; Palomar-Pardavé, M.; Romero-Romo, M.; Ezeta-Mejía, A.; Morales-Gil, P.; Martínez-Huerta, M.V.; Lázaro, M.J. Carbon supported PdM (M = Fe, Co) electrocatalysts for formic acid oxidation. Influence of the Fe and Co precursors. Int. J. Hydrog. Energy 2019, 44, 1640-1649. [CrossRef]

30. Morales-Acosta, D.; Morales-Acosta, M.D.; Godinez, L.A.; Álvarez-Contreras, L.; Duron-Torres, S.M.; Ledesma-García, J.; Arriaga, L.G. PdCo supported on multiwalled carbon nanotubes as an anode catalyst in a microfluidic formic acid fuel cell. J. Power Sources 2011, 196, 9270-9275. [CrossRef] 
31. Zhou, W.P.; Lewera, A.; Larsen, R.; Masel, R.I.; Bagus, P.S.; Wieckowski, A. Size Effects in Electronic and Catalytic Properties of Unsupported Palladium Nanoparticles in Electrooxidation of Formic Acid. J. Phys. Chem. B 2006, 110, 13393-13398. [CrossRef]

32. Zhou, W.; Lee, J.Y. Particle Size Effects in Pd-Catalyzed Electrooxidation of Formic Acid. J. Phys. Chem. C 2008, 112, 3789-3793. [CrossRef]

33. Kiyani, R.; Rowshanzamir, S.; Parnian, M.J. Nitrogen doped graphene supported palladium-cobalt as a promising catalyst for methanol oxidation reaction: Synthesis, characterization and electrocatalytic performance. Energy 2016, 113, 1162-1173. [CrossRef]

34. Jiang, H.; Liu, L.; Zhao, K.; Liu, Z.; Zhang, X.; Hu, S. Effect of pyridinic- and pyrrolic-nitrogen on electrochemical performance of $\mathrm{Pd}$ for formic acid electrooxidation. Electrochim. Acta 2020, 337, 135758. [CrossRef]

35. Hu, S.; Munoz, F.; Noborikawa, J.; Haan, J.; Scudiero, L.; Ha, S. Carbon supported Pd-based bimetallic and trimetallic catalyst for formic acid electrochemical oxidation. Appl. Catal. B Environ. 2016, 180, 758-765. [CrossRef]

36. Wang, Y.; Qi, Y.; Zhang, D. New mechanism of the direct pathway for formic acid oxidation on Pd(111). Comput. Theor. Chem. 2014, 1049, 51-54. [CrossRef]

37. Wang, X.; Xia, Y. Electrocatalytic performance of PdCo-C catalyst for formic acid oxidation. Electrochem. Commun. 2008, 10, 1644-1646. [CrossRef]

38. Chen, D.; Pei, S.; He, Z.; Shao, H.; Wang, J.; Wang, K.; Wang, Y.; Jin, Y. High Active PdSn Binary Alloyed Catalysts Supported on B and N Codoped Graphene for Formic Acid Electro-Oxidation. Catalysts 2020, 10, 751. [CrossRef]

39. Sui, L.; An, W.; Feng, Y.; Wang, Z.; Zhou, J.; Hur, S.H. Bimetallic Pd-Based surface alloys promote electrochemical oxidation of formic acid: Mechanism, kinetics and descriptor. J. Power Sources 2020, 451, 227830. [CrossRef]

40. Ma, T.; Li, C.; Liu, T.; Yuan, Q. Size-controllable synthesis of dendritic Pd nanocrsytals as improved electrocatalysts for formic acid fuel cells' application. J. Saudi Chem. Soc. 2018, 22, 846-854. [CrossRef]

41. Bhalothia, D.; Huang, T.-H.; Chou, P.-H.; Wang, K.-W.; Chen, T.-Y. Promoting formic acid oxidation performance of Pd nanoparticles via Pt and Ru atom mediated surface engineering. RSC Adv. 2020, 10, 17302-17310. [CrossRef]

42. Rettenmaier, C.; Arán-Ais, R.M.; Timoshenko, J.; Rizo, R.; Jeon, H.S.; Kühl, S.; Chee, S.W.; Bergmann, A.; Roldan Cuenya, B. Enhanced Formic Acid Oxidation over $\mathrm{SnO}_{2}$-decorated Pd Nanocubes. ACS Catal. 2020, 10, 14540-14551. [CrossRef] [PubMed]

43. Zhang, X.; Zhu, J.; Tiwary, C.S.; Ma, Z.; Huang, H.; Zhang, J.; Lu, Z.; Huang, W.; Wu, Y. Palladium Nanoparticles Supported on Nitrogen and Sulfur Dual-Doped Graphene as Highly Active Electrocatalysts for Formic Acid and Methanol Oxidation. ACS Appl. Mater. Interfaces 2016, 8, 10858-10865. [CrossRef] [PubMed]

44. Zhou, Y.; Zhu, X.; Zhang, B.; Ye, D.-D.; Chen, R.; Liao, Q. High performance formic acid fuel cell benefits from Pd-PdO catalyst supported by ordered mesoporous carbon. Int. J. Hydrog. Energy 2020, 45, 29235-29245. [CrossRef] 